Check for updates

Cite this: RSC Adv., 2021, 11, 20006

Received 13th November 2020

Accepted 14th January 2021

DOI: $10.1039 / \mathrm{d}$ ra09668g

rsc.li/rsc-advances

\section{A comprehensive overview of vaccines developed for pandemic viral pathogens over the past two decades including those in clinical trials for the current novel SARS-CoV-2}

\author{
Kannan Damodharan, (D) ab Gandarvakottai Senthilkumar Arumugam, ${ }^{\text {b }}$ \\ Suresh Ganesan, ${ }^{\mathrm{b}}$ Mukesh Doble $\mathbb{D}^{* \mathrm{~b}}$ and Sathiah Thennarasu ${ }^{\mathrm{a}}$
}

The unprecedented coronavirus disease 2019 (COVID-19) is triggered by a novel strain of coronavirus namely, Severe Acute Respiratory Syndrome-Coronavirus-2 (SARS-CoV-2). Researchers are working around the clock to control this pandemic and consequent waves of viral reproduction, through repurposing existing drugs as well as designing new vaccines. Several countries have hastened vaccine design and clinical trials to quickly address this outbreak. Currently, more than 250 aspirants against SARS-CoV-2 are in progress, including mRNAreplicating or non-replicating viral vectored-, DNA-, autologous dendritic cell-based-, and inactivated virusvaccines. Vaccines work by prompting effector mechanisms such as cells/molecules, which target quickly replicating pathogens and neutralize their toxic constituents. Vaccine-stimulated immune effectors include adjuvant, affinity, avidity, affinity maturation, antibodies, antigen-presenting cells, B lymphocytes, carrier protein, CD4 ${ }^{+} \mathrm{T}$-helper cells. In this review, we describe updated information on the various vaccines available over the last two decades, along with recent progress in the ongoing battle developing 63 diverse vaccines against SARSCoV-2. The inspiration of our effort is to convey the current investigation focus on registered clinical trials (as of January 08,2021 ) that satisfy the safety and efficacy criteria of international wide vaccine development.
${ }^{a}$ Department of Organic and Bioorganic Chemistry, CSIR-Central Leather Research Institute (CLRI), Chennai, 600020, India
${ }^{b}$ Bioengineering and Drug Design Lab, Department of Biotechnology, Indian Institute of Technology Madras (IITM), Chennai, 600032, India. E-mail: mukesh.dobleo@ gmail.com; mukeshd@iitm.ac.in

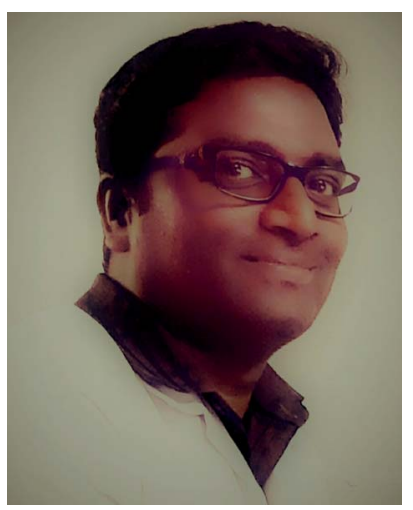

Kannan completed his B.Sc. chemistry degree at A. V. C. College, Mayiladuthurai, affiliated to Bharathidasan University, and M.Sc. in chemical sciences at Pondicherry University, India. He obtained his PhD (organic chemistry) at the University of Madras, India. Later, he took a research associate position at the Department of Biotechnology, IIT Madras, then moved to Taiwan for research at Tamkang University, Taiwan. Then he was employed as a SERB-post-doctoral fellow at the CSIR-Central Leather Research Institute, Chennai, India. He has synthesized substituted alkynylated hybrid molecules and utilized them for NIR and EL applications; and liquid crystalline-, steroidal-based materials for sensor and biomedical applications; he also worked on the characterization of natural product transitmycin.

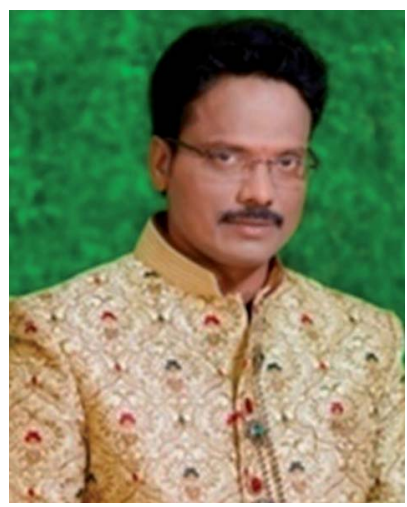

Senthilkumar obtained his M.Sc. chemistry at Bharathidasan University, where he was involved in mechanistic studies of anticancer drugs. He then explored new drug discovery and development from marine and medicinal plants, and their synthesis which is been developed at IIT Madras, IISc Bangalore and IIT Kanpur. He developed variegated drug candidates at IIT Madras, such as phosphate binder resin, sevcar (two patents); and tolvaptan, hyponatremia and cystagon; and drugs from Terminalia arjuna. He then engaged in the peptidomimetic domain for antitumor screening at IISc Bangalore. Then back at IIT Madras worked on transitmycin, which is in phase-II pre-clinical trials. He has also discovered new blood, breast, and liver cancer drugs, and diabetic treatments. Recently, he also discovered, arjunetin, that is a better candidate for COVID-19 treatment than FDA approved drugs. 


\section{Introduction}

One of the most successful therapeutic strategies to prevent or control various diseases is by "vaccination" protocol. ${ }^{\mathbf{1} 2}$ Millions of lives have been saved because of vaccinations, which cover a number of diseases including certain types of cancer, HIV and many viral infections. ${ }^{3}$ Vaccination was initially accomplished by Edward Jenner, who was the pioneer for smallpox in the late $18^{\text {th }}$ century. ${ }^{4}$ In the 1980 s, the development of vaccines to fight against pathogenic microorganisms was tentatively introduced. Vaccines are now employed to improve and increase the protection capability (immunity) of the body to fight severe infection and disease, ${ }^{5}$ and moreover, primarily intend to make immunity stronger and reduce resistivity of diseases by reducing the reproduction of target pathogens. The majority of vaccines actively exist in the immune system, since anti-bodies are constantly generated in the body to sustain a healthy immunity system. ${ }^{6,7}$

\section{General components of vaccines}

A vaccine consists of an antigen, stabilizer, adjuvant, antibiotic, preservative, and chemical reagents such as formaldehyde. ${ }^{8}$ The advantages and disadvantages of vaccinations ${ }^{9 a}$ are listed in Table 1.

Antigen. The component matching the structural array of disease-oriented organisms, wherein, they are identified by the immune system as 'foreign' and cause an active immune response.

Stabilizer. This module is employed to assist the vaccine by sustaining its efficiency during storage. Instability of the vaccine can lead to reduced antigenicity and decreased infectivity of live attenuated vaccine (LAV). Magnesium chloride $\left(\mathrm{MgCl}_{2}\right)$ for oral polio vaccine (OPV), magnesium sulfate $\left(\mathrm{MgSO}_{4}\right)$ in measles vaccines, and lactose and gelatin associated with sorbitol, are current representatives of stabilizing factors.

Adjuvant. They are responsible for enhancing the efficacy of the vaccine by motivating the generation of antibodies.

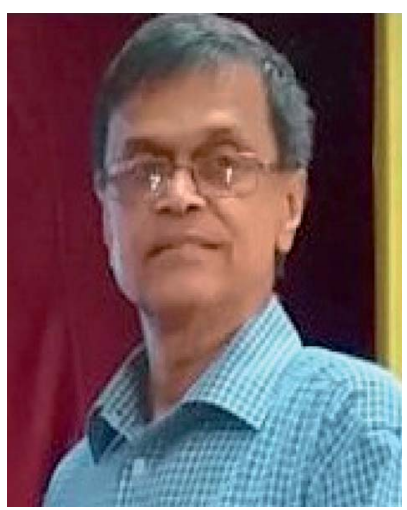

Doble is a professor (Emeritus) in the Department of Biotechnology at the Indian Institute of Technology Madras (IITM). $\mathrm{He}$ worked for 23 years at Imperial Chemical Industries and General Electric Technology centers. His areas of interest are biomaterials, drug design, bioreactors and bioremediation. He holds $B$. Tech and $M$. Tech degrees in chemical engineering (IITM), and a PhD (University of Aston, Birmingham, UK) and has postdoctoral experience (University of Cambridge, UK, and Texas A \& M, USA). He has authored 320 technical papers, 10 books, and filed 15 patents and is a director of two startup biotechnology companies.
Chemically, adjuvants are a highly heterogeneous group of compounds (including Al salts).

Antibiotics. Used in lower amounts during the development phase, to circumvent bacterial infection during tissue culture cells where the viruses are grown. MMR (measles, mumps, rubella) and IPV (inactivated polio vaccine) associated vaccines have a minimum amount $(<25 \mu \mathrm{g})$ of neomycin for each dose.

The MMR vaccine was developed by Maurice Hilleman in 1971. Mumps, like measles infections, are caused by an RNA based virus from the Paramyxoviridae family. Moreover, measles and mumps belong to the genus Rubulavirus, it is a human disease with no animal reservoirs. Generally, the MMR vaccine exhibits side effects of a painful arm from the shot, minor rashes, generally in teen/adult women who have no earlier immunity; then the rubella vaccine component can result in joint and tendon stiffness. This vaccine is also associated with the minor threat of seizures/jerking instigated by fever, but is not connected with any enduring effects. The threat of febrile seizures increases as infants get older, hence this vaccine is recommended at a young age. Some people may experience cheek/neck inflammation, impermanent low platelet counts that generally do not require treatment and are also not life threatening. ${ }^{9 b}$

In 1955, Jonas Salk initiated an inactivated polio vaccine (IPV), after that, Albert Sabin further developed the live, OPV. Even though poliovirus has three serotypes, both vaccines are trivalent and offer good resistivity against poliomyelitis, a limited number of countries have continuously provided IPV. Sabin's OPV vaccine is underused in most countries due to minimising oral management, but it advances immunity in the intestine, which is capable of spreading to others, and is associated with lower cost. ${ }^{9 c}$

Preservatives. They are added in multi-dose vaccines, which can be used to control bacterial and fungal growth, including thiomersal (sodium(2-carboxylatophenyl)sulfanyl-ethyl mercury), formaldehyde, or phenolic derivatives. In fact, formaldehyde is responsible for inactivating the viruses (e.g. IPV) and removing toxicity in bacterial strains, including the toxin employed in diphtheria and tetanus vaccines.

\section{Types of vaccines}

Various kinds of vaccines are available and those which are administered to infants and adults can be classified (Fig. 1) as follows:

- Live-attenuated.

- Inactivated.

- Toxoid.

- Conjugate.

- Subunit.

Live attenuated vaccines. These vaccines are adapted from the existing bacteria or virus, they have been weakened, and thus will not result in serious disease in people with strong immunity. LAV vaccines are more similar to the actual infection. A few representative examples are the MMR and varicella (chickenpox) vaccines. Albeit, it is efficient, but not everyone 
Table 1 Advantages and disadvantages of vaccines

\begin{tabular}{ll}
\hline Advantages & Disadvantages \\
\hline Protection of inhabitants against disease & Uncertainty about complete protection \\
Preventing epidemic and pandemic diseases & May have some possible side effects \\
Prevents diseases spreading to others & Requires NHS/individual outlay \\
Avoids large cost for the treatment of infected patients & Injections are not pleasant/more immune booster injections are inconvenient
\end{tabular}

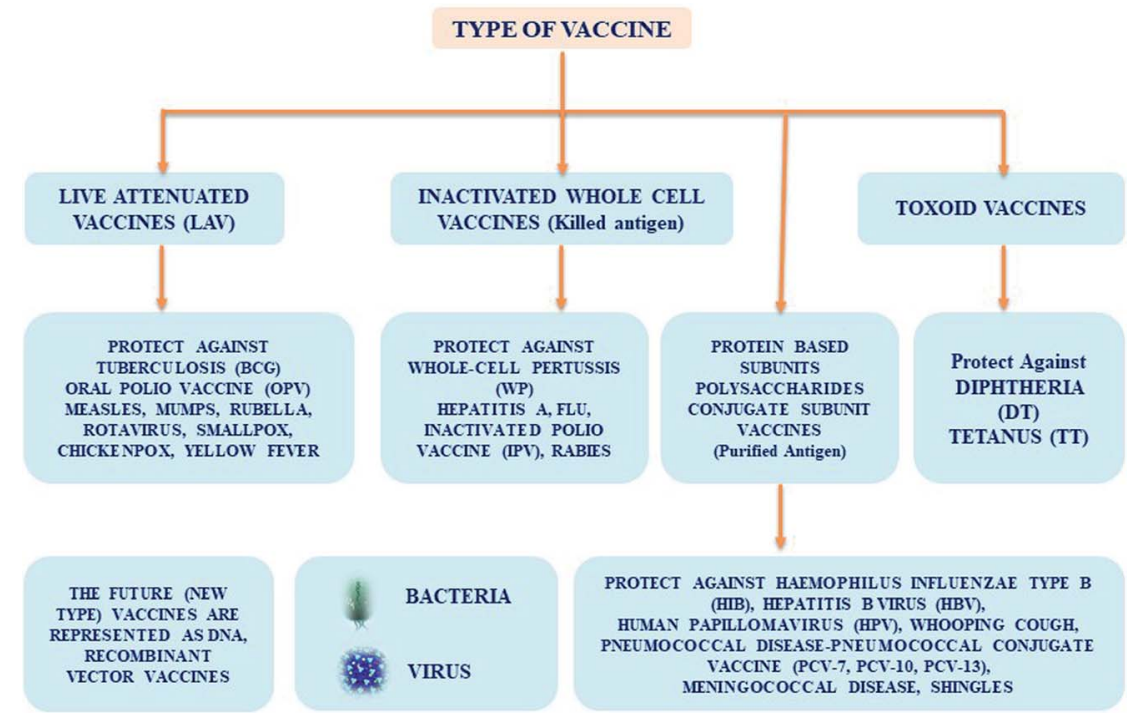

Fig. 1 Pictorial representation of vaccine types.

can be administered these vaccines, including children and patients undergoing chemotherapy as their immune system is too weak.

Inactivated vaccines. These vaccines are made from inactivated or dead organisms. The polio vaccine is an example of an inactivated vaccine, which generates an immune response through various routes different to the live attenuated vaccine. It requires a higher dosage to increase and/or sustain immunity.

Toxoid vaccines. This vaccine prevents the disease resulting from the toxins released by a virus into the body. Since the toxic substances administered are weak they are unable to cause the illness, while the immune system which encounters this toxoid vaccine, becomes able to repel the natural toxin. The DTaP vaccine for diphtheria and tetanus toxoids falls into this category.

Conjugate vaccines. They defend the system against different kinds of bacteria which have antigens that are surface coated with polysaccharide units. It is obvious, that this sugar coated unit masks the antigen. These vaccines append (or conjugate) themselves to the polysaccharide units on the antigens. Haemophilus influenzae type B (Hib) vaccine is an example of the conjugate type.

Subunit vaccines. These vaccines are made up of simple fractions of the virus/bacteria or subunits, rather than the complete germ. Since the subunit vaccines have an essential antigen only and are not the molecular array constituting the germ, they have less side effects. The DTaP vaccine-pertussis (whooping cough) module is a paradigm of subunit vaccines.

\section{Common characteristics of vaccines}

Live attenuated vaccines are typically grown in animal cell lines under poor development conditions. The development of an inactivated vaccine involves use of thermal or chemical methods in the beginning, and its mode of action involved in conferring immunity is not fully known. However, the live attenuated or execution of entire organism-supported vaccines have shown a lot of success in the control and inhibition of severe transmittable diseases in human, including animal infectious cattle plague, classic swine fever, equine infectious anaemia, measles, mumps, polio, rubella, smallpox, and so on. In recent times, the use of LAVs, subunit and peptide based vaccines have become possible because of progressive technologies in molecular biology. LAVs are based on the mechanism of action associated with the immune response. Inactivated vaccines, based on antibodies have been mostly used to prevent and manage microbial infectious diseases. LAVs introduce stronger cell immune responses that are decisive to remove several intracellular viral pathogens. However, these pathogens sometimes bypass inactivated vaccines ${ }^{9 \boldsymbol{d}}$ by mutating peripheral antigens. On the other hand, subunit and peptide based vaccines are less efficient in drawing a strong $\mathrm{CD} 8^{+}$ immune response. 
Progressive vaccination involves the use of non-viral distributed nucleic acid-supported vaccines, which imitate live microorganism infection- or immunization. This leads to T-helper cellular immune responses. In addition, this vaccine development ${ }^{9 e_{f} f}$ is harmless and consumes less. It does not require extreme infectious organisms, so is safe from infectivity through live transmittable agents and the discharge of harmful pathogenic organisms. These vaccines fill the gap between a virus outbreak and design of a desirable vaccine, wherein they are classified as DNA/RNA based pentose-carbon sugar motif. The remarkable growth of RNA-associated vaccines resulted in the growth of mRNA based vaccines. It is quite significant to note that mRNA vaccines provide many valuable benefits when compared to viral vectored- and DNA vaccines. $^{\mathbf{1 0}}$

\section{Proceedings of vaccination against viral diseases}

In 1970, to evade the prevalent spread of foot and mouth disease, scientists discovered a vaccine using a single protein from the virus. Despite their achievements in virology, in particular vaccine studies and their development, the lack of understanding of immunological mechanisms of action during induced defensive immunity, has prevented the use of existing vaccines during global pandemic outbreaks of related diseases with similar viral pathogens. The immune system protects against various pathogens, including distinctive units of $\mathrm{T}$ helper cells that are useful to protect against various unusual pathogens. Besides, the follicular $\mathrm{T}$-helper cells $\left(\mathrm{T}_{\mathrm{FH}}\right.$ cells) generate interleukins (ILs) and support the partition of B cells (they are lymphocytes, and take part in the humoral immune response) and generation of Memory B cells. Furthermore, Memory $\mathrm{T}$ cells can be sub classified as $\mathrm{CD} 4^{+} / \mathrm{CD}^{+} \mathrm{T}$ cells (Cluster of Differentiation) and their functionalities are (a) central memory and (b) effectors memory, which provide various responses upon vaccination against different pathogens. ${ }^{11}$ Different vaccines attempted for identical pathogens depend on the perceptions of the scientist, ${ }^{\mathbf{1 2}}$ many healthcare professionals do not pay sufficient attention to vaccines, which may result in uncertainty in their efficacy, side effects and toxicity. Table 2 lists the various vaccines discovered that are available in the current market for protection against viral infections. They are listed on the basis of various factors, ${ }^{\mathbf{1 3 , 1 4}}$ including the apparent protection level, plausible mechanism of action, possibility of usage for other diseases. ${ }^{15,16}$

\section{Mode of action stimulated by vaccines}

Normally antibodies prevent/minimize infections from extracellular pathogens:

(a) use enzymatic active sites to fuse to toxins to break their diffusion;

(b) prophylactic action preventing viral replication;

(c) facilitate opsonophagocytosis of extracellular bacteria;

(d) inducing the complement cascade.
$\mathrm{CD}^{+} \mathrm{T}$ cells do not inhibit infection but work to minimize, regulate, and remove intracellular pathogens through:

(a) direct destruction of infected cells (discharge of perforin a pore forming cytolytic protein present in cytotoxic $\mathrm{T}$ lymphocytes (CTLs) and natural killer (NK) cells), granzyme (serine proteases delivered through cytoplasmic granules inside cytotoxic T cells and NK cells);

(b) destroy infected cells with antimicrobial cytokine release.

$\mathrm{CD}^{+} \mathrm{T}$ cells do not inhibit infection, however they contribute in the minimization, regulation, and refinement of extra- and intra-cellular pathogens with their control and cytokinedevelopment capabilities. The main examples of $\mathrm{CD}^{+} \mathrm{T}$ cells are:

(a) Follicular T-helper (Tfh) cells yielding predominantly interleukin (IL)-21 and providing assistance to B-cells;

(b) T-helper 1 (Th1) effector cells yield interferon (IFN)- $\gamma$, (TNF)- $\alpha / \mathrm{TNF}-\beta, \mathrm{IL}-2$, and provide a major role in controlling intracellular pathogens e.g., viruses and bacteria such as $M$. tuberculosis;

(c) Th2 effector cells generate IL-4, IL-5, IL-13, and impact extracellular pathogens such as bacteria and helminths;

(d) Th9 effector cells generate IL-9 and also defend against extracellular pathogens;

(e) Th17 effector cells generate IL-17, IL-22, and IL-26 and participate in mucosal protection (for example against, $S$. pneumoniae, B. pertussis, M. tuberculosis).

\section{Main effectors of vaccine responses}

Vaccines prevent disease by inducing effector modes of action in cells/molecules to reduce the development of pathogens and deactivate their toxic effects. Vaccine-stimulating immune effectors are resourceful antibodies generated by B lymphocytes' ability to interact to a particular toxin/pathogen. A pictographic representation of vaccine immunological function is shown in Fig. 2 .

Isotype switching. Control of immunoglobulin (Ig) expression and production from IgM yielding IgG, IgA, or IgE that ensues through B-cell differentiation by DNA recombination.

Marginal zone. The zone between the spleen's red pulp and white pulp is known as marginal zone. Its main function is to catch particulate antigens from the circulation and distribute them to lymphocytes.

Pattern recognition receptors. These germline-encoded receptors sense the existence of infection through the identification of pathogenic microbe molecular arrays, and stimulate innate immune responses.

Regulatory T cells-t. T cells secrete cytokines (IL-10, transforming growth factor [TGF]- $\beta$ /surface markers) and react to reduce immune system response through different modes of action, this sustains immune homeostasis and tolerance to self-antigens.

Resident memory $\mathbf{T}$ cells. Effector memory $\mathrm{T}$ cells exist in particular tissues (such as the lungs, gut, and skin) and are an instant and early line of protection against various viral and bacterial pathogens.

Somatic hypermutation. This is a process which intercalates unsystematic mutations in the $\mathrm{B}$-cell receptor region (i.e., 
Table 2 The various antiviral vaccines available in the last two decades, and their characteristics

Characteristic vaccines

S.

no. Generic name

Picovax IPV vaccine, Inactivated Polio Danish Medicines Vaccine (IPV)

Agency

2 Grippol plus

3 Ys-On-001

4 Adimmune's quadrivalent flu vaccine Taiwan (4142)

5 Quadrivalent influenza vaccine (J0\&BB02)

Vaxigrip Tetra QIVSanofi Split influenza virus Pasteur

Yivyka polyinosinicpolycystidylic acid/ inactivated rabies virus Yisheng Biopharma
Polymer supported inactivated influenza vaccine 3-valent, egg derived adjuvanted influenza vaccine, polyoxidonium as a distinct adjuvant Cancer vaccines antineoplastics
Monovalent vaccine, egg-based inactivated split virus, influenza H1N1 vaccine vaccine
Attenuated zoster-, varicella-type vaccine
Treatment for other

diseases

Year of

Mode of action

IPV provides serum

immunity to each

Diphtheria, whooping 2019

cough, tuberculosis,

poliovirus (three types) tetanus, polio and

and defence against any bladder cancer

ensuing paralysis

causative disease

(poliomyelitis). The

mucosal immunity level

in the intestine is less

than that afforded by

OPV, this difference may

slightly show in the

pharyngeal mucosal

lining. Prevents

poliovirus in the nervous

system;

immunostimulant

Vaccine primes

To treat influenza virus 2018

18

advanced meticulous infection $(\mathrm{A} / \mathrm{H} 1 \mathrm{~N} 1+\mathrm{A} /$

anti-influenza immunity H3N2)

formation;

immunostimulant

B-cell stimulant,

Cancer vaccines

2017

19

cytokines stimulant, pancreatic cancer

dendritic cell stimulant,

immune-modulator,

macrophage modulator,

natural cell stimulant,

regulatory $\mathrm{T}$ lymphocyte

inhibitor, Th1 cell

stimulant

Immunostimulants;

inactivated virus from

chick embryo culture

split virus

Induces the humeral

antibodies against

hemagglutinins

inhibition (HAI) within

2-3 weeks; antibodies

neutralize the influenza

viruses

Inducing both humoral Varicella-zoster virus 2017

and cellular immune (VZV), a human

response, which creates neurotropic alpha-

an IgG humoral immune herpes-virus. Major

response; varicella- infection causes

zoster specifically varicella (chickenpox)

activate $\mathrm{CD}^{+}{ }^{+} \mathrm{T}$-helper

and $\mathrm{CD}^{+}{ }^{+} \mathrm{T}$-lymphocyte

cells

Hepatitis B virus used Immune-stimulatory Treatment of HBV-, HIV 2017

1018, adjuvant proceeds

TLR-9 agonist, which is

used for potential

prevention and

treatment of HIV

infection 
Table 2 (Contd.)

\section{Characteristic vaccines}

\begin{tabular}{|c|c|c|c|c|c|}
\hline $\begin{array}{l}\text { S. } \\
\text { no. Generic name }\end{array}$ & Trade name & Type & Mode of action & $\begin{array}{l}\text { Treatment for other } \\
\text { diseases }\end{array}$ & $\begin{array}{l}\text { Year of } \\
\text { approval Ref. }\end{array}$ \\
\hline
\end{tabular}

8 GSK-1437173A Shingrix GSK

9 DTPa-hepB-IPV-Hib

EasySix, Hexaxim Panacea Biotech

11 Tetravalent inactivated Vaxiflu-4 Zydus Cadila Influenza vaccine influenza vaccine (TIV)

10 Ad5-EBOVJ07BX02

ErveboBIB, CanSinoBIO Glycoprotein recombinant adenovirus replication deficient recombinant aden
type 5 Ebola virus vaccine

6 in 1 combination The body produces its Infanrix hexa whole cell own antibodies to pertussis antigen

protect against bacteria and viruses causing different infections Recombinant

Antigen IgE and adjuvant To prevent herpes zoster 2017 24 subunit vaccine; system AS01B develop (HZ) infection

vacine herpes VZV-specific immune zoster $(\mathrm{Hz} / \mathrm{su})$ response in a weakening

immune system. Generates a long-term immune response, Shingrix helps to address age-related decline in shingles immunity

10 Ad5-EBOVJ07BX2 human Ad5 vector stimulating immune responses and defending against the Ebola virus

To increase immunity by Treating influenza generating antibody viruses-H1N1, H3N2, proteins, which defend Type B (Brisbane and against infection caused Phuket)

by the virus present in the vaccine

12 Flu Vac Qs 2019-20 (4 Yr Flucelvax Quadrivalent Cell based flu vaccines Up) CD,BL-125408 Seqirus, Inc

13 Quadrivalent influenza Vaxigrip TetraSanofi vaccine (QIV) (GQM-10)

Inactivated influenza vaccine (split version)

Attenuated virus FluMist Quadrivalent

14 Live attenuated influenza vaccine (LAIV) Influenza TetraJ07BB03 Medimmune
15 Enterovirus type 71 vaccine (Vero cells)

16 Inactivated influenza vaccine

Cadiflu-S CBL

Biologicals Pvt. Ltd

17 Inactivated quadrivalent Afluria Quad 2020 influenza vaccine (split Seqiruspty Ltd version)

18 Riv-4 (RIV4)

19 Gam Evac Combi

Inlive SINOVAC
Flublok-QSonofi Pasteur Quadrivalent recombinant influenza vaccine

Combined Vector Based Heterologous VSV and Vaccine antigen vaccine

Inactivated vaccine adenovirus type-5 vectored Ebola virus
Vaccine motivates the To prevent influenza A 2016

body to produce its own and B viruses

immunity (antibodies)

against the virus

To enhance the

protection from

To protect against 2016

circulating influenza B viruses

LAIVs induce $\mathrm{T}$ cell antibody-reactions against the surface protein of HA and NA; LAIVs provide heterosubtype protection in humans

Inactivated EV 71 virus Generate immune reactions against EV71 virus

To develop immunity against the disease by forming antibodies influenza (flu) viruses

To prevent common flu; 2016 influenza A-(H1N1), (H3N2), and B-viruses influenza-B type viruses and

Humoral immune response measured by hemagglutination inhibition antibodies Heterologous primeboost vaccine humoral immune response, cell facilitated immune response to Ebola

To prevent hand-foot- 2016 caused by EV-71 To prevent influenza $\quad 2016 \quad 32$ and protect against its effects

Diphtheria, DTP, $2017 \quad 25$ Hepatitis B, Hib, IPV,

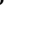


Table 2 (Contd.)

\section{Characteristic vaccines}

\begin{tabular}{|c|c|c|c|c|c|c|c|}
\hline $\begin{array}{l}\text { S. } \\
\text { no. }\end{array}$ & Generic name & Trade name & Type & Mode of action & $\begin{array}{l}\text { Treatment for other } \\
\text { diseases }\end{array}$ & $\begin{array}{l}\text { Year of } \\
\text { approval }\end{array}$ & Ref. \\
\hline 20 & $\begin{array}{l}\text { In32 Activated Sabin } \\
\text { polio vaccine }\end{array}$ & Ai Bi Wei IMB China & $\begin{array}{l}\text { Inactivated Poliomyelitis } \\
\text { (IPV) }\end{array}$ & $\begin{array}{l}\text { Inactivated vaccines } \\
\text { offer immunity by } \\
\text { delivering an inactivated } \\
\text { antigen. This vaccine } \\
\text { cannot cause disease, } \\
\text { thus, it may be } \\
\text { administered to an } \\
\text { immuno-compromised } \\
\text { host }\end{array}$ & $\begin{array}{l}\text { To prevent polio in new } \\
\text { born babies }\end{array}$ & 2015 & 36 \\
\hline 21 & Rotavirus Orv-116E & $\begin{array}{l}\text { ROTAVAC 5D Vero cells } \\
\text { Derived Bharath Biotech }\end{array}$ & $\begin{array}{l}\text { Rotavirus vaccine live } \\
\text { attenuated monovalent }\end{array}$ & $\begin{array}{l}\text { Rotarix (vaccine } \\
\text { prevents rotavirus }\end{array}$ & $\begin{array}{l}\text { To prevent rotavirus } \\
\text { gastroenteritis }\end{array}$ & 2015 & 37 \\
\hline
\end{tabular}

22 NBP-607-QIV

23 GC-3110A, GC-3110B

24 Chimerivax-dengue (CYD-TDV)

25 H5N1 influenza (avian flu) vaccine $(\mathrm{Rx})$ vaccine

Derived Bharath Biotech attenuated monovalent

SKY cell flu Quadrivalent Cell cultured quadrivalent ina subunit influenza vaccine

GCflu Quad GC Pharma Quadrivalent influenza virus vaccine

Dengvaxia Sanofi Pasteur

Audenz Vn-101 Sonali Pasteur GSK
26 9-Valent HPV vaccine [9v GARDASIL 9 HPV]

27 Cell cultured-H5N1 vaccine $\mathrm{KD}-295$
GSK
Live attenuated tetravalent chimeric vaccine Egg based H5N1 vaccines, inactivated influenza virus vaccine influenza HA vaccine (Prototype) infectivity) reproduces

in the small intestine

and induces immunity; the particular mechanistic action of immunology by rotarix against rotavirus gastroenteritis is unknown Immunity for influenza viruses $A$ and $B$ subtypes. Seroprotection is generally obtained within three weeks

Hemagglutination inhibition antibody response Antibody dependent improvement

Induces immunity (antibodies), which act against viral $\mathrm{HA}$ in the vaccine, after interrupting viral attachment to human respiratory cells, provides immunity to influenza A virus subtype H5N1 Prevent HPV through humoral immune responses induced by the vaccine

Antibody titer calculated To prevent influenza A through hemagglutination inhibition (HI): hightiter virus generation led to suspension of growth of MDCK (Madin-Darby Canine Kidney) and Vero cells in a serum-free distribution
To treat influenza virus $2015 \quad 39$ infections

To prevent Dengue 2015 virus-1, 2, 3 and 4 fever in humans

To treat influenza virus $\quad 2014 \quad 41$

Prevention of cervical, 2014 , vaginal, anal, or pharyngeal, head and neck cancer; by preventing papilloma virus (HPV) infection virus $\mathrm{H} 5 \mathrm{~N} 1$

2014 
Table 2 (Contd.)

\section{Characteristic vaccines}

\begin{tabular}{|c|c|c|c|c|c|c|c|}
\hline $\begin{array}{l}\text { S. } \\
\text { no. }\end{array}$ & Generic name & Trade name & Type & Mode of action & $\begin{array}{l}\text { Treatment for other } \\
\text { diseases }\end{array}$ & $\begin{array}{l}\text { Year of } \\
\text { approval }\end{array}$ & Ref. \\
\hline 28 & $\begin{array}{l}\text { Live modified vaccine } \\
\text { virus Ankara Ankara- } \\
\text { Bavarian Nordic (MVA- } \\
\text { BN)-J07BX }\end{array}$ & $\begin{array}{l}\text { IMVANEX/IMVAMUNE } \\
\text { JYNNEOS }\end{array}$ & $\begin{array}{l}\text { Non-replicating small } \\
\text { pox vaccine }\end{array}$ & $\begin{array}{l}\text { Non-replicating and } \\
\text { capable of generating } \\
\text { humoral and cellular } \\
\text { immune response to } \\
\text { orthopox-viruses }\end{array}$ & To prevent smallpox & 2013 & 44 \\
\hline 29 & $\begin{array}{l}\text { Japanese encephalitis } \\
\text { vaccine BBIL/JEV }\end{array}$ & JENVAC Bharath Biotech & $\begin{array}{l}\text { Inactivated Vero cell- } \\
\text { derived viral vaccine }\end{array}$ & $\begin{array}{l}\text { JENVAC is sufficient to } \\
\text { elicit an immune } \\
\text { response }\end{array}$ & $\begin{array}{l}\text { To protect against } \\
\text { Japanese encephalitis } \\
\text { virus (JEV) }\end{array}$ & 2013 & 45 \\
\hline 30 & $\begin{array}{l}\text { Fluzone quadrivalent BL } \\
\text { 103914/J07B B }\end{array}$ & $\begin{array}{l}\text { FLUZONE Quadrivalent } \\
\text { Sanofi Pasteur Inc. }\end{array}$ & $\begin{array}{l}\text { Inactivated quadrivalent } \\
\text { influenza virus vaccine } \\
\text { type A and type B (split } \\
\text { version) }\end{array}$ & $\begin{array}{l}\text { Stimulates the } \\
\text { production of specific } \\
\text { antibodies }\end{array}$ & $\begin{array}{l}\text { Prevents influenza } \\
\text { diseases, type A and B }\end{array}$ & 2013 & 46 \\
\hline 31 & $\begin{array}{l}\text { FLU-Q-QIV flu laval } \\
\text { quadrivalent GSK- } \\
2282511 \mathrm{~A}\end{array}$ & $\begin{array}{l}\text { FluLaval }^{\mathrm{TM}} \text { Quadrivalent } \\
\text { Glaxo Smith Kline (GSK) }\end{array}$ & Influenza virus vaccine & $\begin{array}{l}\text { Vaccines which improve } \\
\text { immunity against the } \\
\text { viral pathogen leading to } \\
\text { influenza: they induce } \\
\text { the generation of } \\
\text { antibodies }\end{array}$ & $\begin{array}{l}\text { Prevents influenza } \\
\text { diseases, type A and B }\end{array}$ & 2013 & 47 \\
\hline 32 & $\begin{array}{l}\text { DTa-IPV-HePB- } \\
\text { HibHexavalent vaccine6- } \\
\text { in-1 vaccine J07CA09 }\end{array}$ & Hexyon, Infanrix, Vaxelis & Hexavalent vaccine & Booster vaccination & $\begin{array}{l}\text { To treat DTaP, hepatitis } \\
\mathrm{B} \text {, polio, haemophilus } \\
\text { influenza diseases }\end{array}$ & 2013 & 48 \\
\hline 33 & $\begin{array}{l}\text { GSK-2282512a BL } \\
125127\end{array}$ & $\begin{array}{l}\text { Fluarix Quadrivalent } \\
\text { (FLU Q-QIV) Glaxo Smith } \\
\text { Kline Biologicals }\end{array}$ & $\begin{array}{l}\text { Inactivated influenza } \\
\text { vaccine, quadrivalent, } \\
\text { seasonal }\end{array}$ & $\begin{array}{l}\text { Increases immunity for } \\
\text { treatment of disease } \\
\text { originating from } \\
\text { influenza-A subtype and } \\
\text { type B viruses }\end{array}$ & $\begin{array}{l}\text { Prevents disease } \\
\text { triggered by influenza A } \\
\text { subtype and type B } \\
\text { viruses }\end{array}$ & 2012 & 49 \\
\hline
\end{tabular}

34 ChimeriVax $^{\text {TM }}$-JE IMOJEV Sanofi

35 Prepandemic influenza Vepacel vaccine (H5N1) J07BB01

36 Medi-3250STN: 125020

37 Hepatitis E hecolin (HEV-239)

38 Measles/rubella vaccine German measles

39 Human inactivated influenza vaccine (H1N1) 2009 vaccine. Pandemic influenza strain A/California/7/ 2009/nyMC X-179A Med-Immune

Biotech

HNVAC (Bharath Biotech)
Live attenuated Japanese encephalitis vaccine (JEV), monovalent

IMOJEV is highly

immunogenic and able virus

to induce continuing

immunity through both preclinical and clinical trials

Inactivated flu strain Overall the vaccine known as A/Vietnam/ primes the immune

Protect against influenza 2012 H5N1 (bird flu)

1203/2004 (H5N1) whole system

virion, derived from

inactivated Vero cells

FLUMIST Quadrivalent

Influenza vaccine, live attenuated influenza vaccine (LAIV)

Hecolin Xiamen Innovax Non enveloped virus

To provide immunity against influenza virus caused by subtypes A and $\mathrm{B}$

with positive sense HEV induces a strong antivaccine, a recombinant HEG IgG response, vaccine

through early antibody mobilisation

Live attenuated (weakened) viruses

Immunostimulant, produces antibodies (associated proteins fight and kill measles, mumps, and rubella (MMR) viruses

nactivated Influenza A Active immunization virus vaccine (H1N1). agent, which acts Cell culture derived against the influenza $\mathrm{A}$ vaccine
(H1N1) 2009 virus
Protects against

E virus 
Table 2 (Contd.)

\section{Characteristic vaccines}

\begin{tabular}{lll}
$\begin{array}{l}\text { S. } \\
\text { no. Generic name }\end{array}$ & Trade name & Type \\
\hline $\begin{array}{l}\text { Influenza A virus } \\
\text { (H1N1), monovalent } \\
\text { vaccine }\end{array}$ & $\begin{array}{l}\text { 2009 Influenza A } \\
\text { (H1N1), Sonali Pasteur }\end{array}$ & $\begin{array}{l}\text { Monovalent vaccine, } \\
\text { adjuvant }\end{array}$
\end{tabular}

41 Quadrivalent flu vaccine FLUCELVAX

Cellular influenza vaccine

42 Influenza vaccine (whole Vaxiflu-S Fluzone Zydus Inactivated influenza virion). Inactivated Cadila Healthcare Ltd vaccine (NZ) combination

43 H1N1 pandemic Celvapan Baxter influenza vaccine $\mathrm{H} 5 \mathrm{~N} 1$ International strain of the flu virus $\mathrm{A} /$ Vietnam/1203/2004Flu strain/California/07/ 2009 (H1N1) virus

44 Influenza A virus vaccine Fluval P-H5N1

H5N1 Omninvest

45 Non adjuvant influenza Panenza Sanofi-Pasteur Non-adjuvanted A (H1N1) 2009 monovalent vaccine. Influenza hemagglutinin (HA) A/ California/07/2009 (H1N1) V-like virus

46 Monovalent, cell culture- Celtura derived, inactivated subunit influenza vaccine. Produced from A/California/07/2009 (H1N1) with adjuvant MF-59

47 Pandemic (H1N1) ASO3 Pandremix GSK adjuvanted influenza vaccine

48 Influenza vaccine Focetria (H1N1) flu strain from A/ California/7/2009 (H1N1) derived strain NYMC-181 J07BB02

49 Cell culture-derived adjuvanted influenza virus vaccine (Grippol TC

Grippol NeoSolvay pharmaceutical AbbVie influenza vaccine

Cell based adjuvanted

50 Inactivated $\mathrm{H} 5 \mathrm{~N} 1$ Pan-flu (Sinovac influenza (avian flu) Biotech) vaccine A/Vietnam/1194/ 2003/(H5N1) RG
Mode of action

Treatment for other

Year of

diseases

approval Ref.

Active immunization for To prevent influenza A $2010 \quad 56$

preventing disease viral disease

caused by influenza

virus A (H5N1)

Active immunization for To defend against four 2010

preventing influenza different strains of

subtypes A and B

influenza for both subtypes A and B

Active immunization for To assist in protection

2010

preventing Vaxiflu-X against influenza

Motivates the immune

system to produce

antibodies when

To protect against the

2009

exposed to the virus

influenza strains of

H5N1 virus

Fluval affords active immunization against

To prevent influenza

2009

60

four virus strains; two

a (H5N1)

for influenza A subtype,

and two for B type pandemic vaccine

Combination of H1N1 virus antigen and adjuvant system of H1N1

Surface antigen (hemagglutinin and neuraminidase) inactivated adjuvant

Induces a high immune To prevent influenza A 2009

(antibody) response,

(H5N1)

three weeks post-

vaccination

MF-59 adjuvanted cell H1N1 pandemic influenza vaccine response in adults and substantially develops the response with growth of HA-specific $\mathrm{Tfh}\left(\mathrm{CD} 4^{+}, \mathrm{ICOS}+\right.$, CXCR5+, IL-21+) cells Enhances the natural immunity of the body

Vaccine acts by priming To protect against the immune system

Activates the endosomal To prevent influenza non-specific activation of the surface TLRs, which induce the intracellular signals contributing to the antiviral mechanism Body reacts by creating Single shot vaccine antibodies 2009 influenza type A (H1N1) 2009 virus 2009

To prevent influenza A 2009 (H1N1), swine flu viral infections virus infections

To prevent H5N1 2008 65

62 pandemic influenza 
Table 2 (Contd.)

\section{Characteristic vaccines}

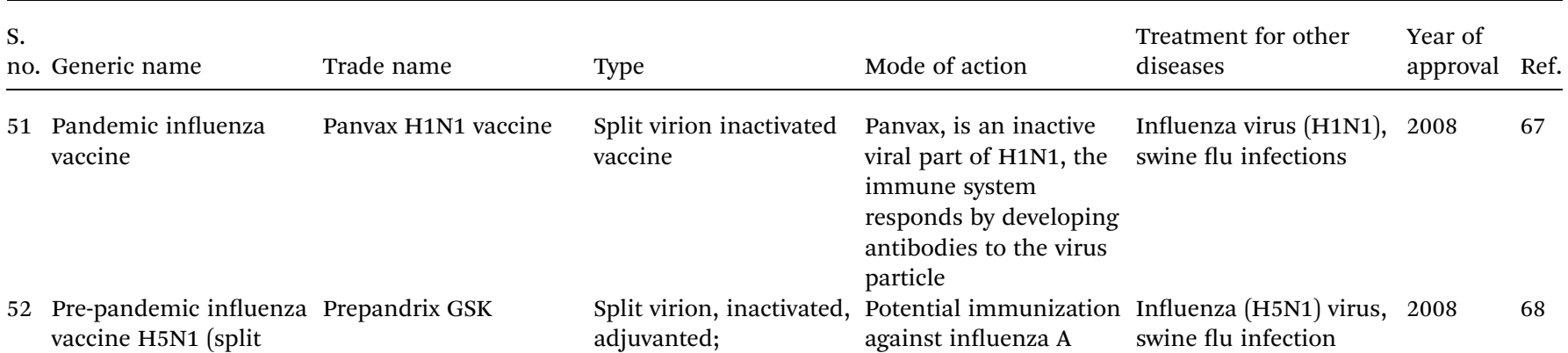

52 Pre-pandemic influenza Prepandrix GSK vaccine H5N1 (split virion, adjuvanted, inactivated) AS03-H5N1 vaccine $\mathrm{A} /$ Vietnam/1194/ 2004; or A/Indonesia/5/ 2005 GSK-1562902a

53 Influenza vaccine (surface antigen, inactivated, prepared in cell cultures) J07BB02

\section{Optaflu Flucelvax TETRA} Novartis

54 Smallpox (vaccinia) vaccine ACAM 2000
Acam-2000 Sanofi Pasteur Biologics Co.
Split virion, inactivated, adjuvanted; hemagglutinin, antigen, subtype $\mathrm{H} 5 \mathrm{~N} 1$ virus adjuvanted and neuraminidase subunit vaccines

The vaccine is made from a live virus, unknown viral components and produce antibodies against them

Possessing potent swine flu infection antigens, hemagglutinin different strain surface vaccinia

55 Inactivated quadrivalent Afluria Seqirus Pty. Ltd. Quadrivalent split influenza vaccine (split virion)

56 H5N1 avian flu vaccine, Fluzone Sanofi Pasteur avian influenza or bird flu, vaccine is derived from A/Vietnam/1203/ 2004 influenza virus

57 Adjuvanted H5N1 pre- Daronix, GSK pandemic vaccine

58 Influenza vaccine surface antigen, inactivated, prepared in cell culture: $\mathrm{A} /$

California/7/2009 (H1N1) pdm09-like strain, A/Switzerland/ 9715293/2013 (H3N2)like strain, B/Phuket/ 3073/2013-like strain

59 Birch pollen allergy vaccine
Oralgen Birch Pollen ALK-Abello virion, influenza virus hemagglutinin as the active ingredient.

Inactivated influenza virus vaccine

Optaflu

Second generation pandemic vaccine

Vaccine containing flu surface antigen

and

Prevent influenza viral 2008 infection

different strain surface
regions of the flu virus. Vaccine causes immune system to recognize the immunization against smallpox

Immunity against 3

(type A (2) and type B (1)) by influenza virus

or 4 (type A (2) and type

B (2)) microbial strains.

Suitable for the annual

flu season

Provides protection against the $\mathrm{H} 5 \mathrm{~N} 1$

influenza virus

To prevent infection

2007 caused by influenza virus

stimulating the immune response

Prepare the body's immune system to prevent a flu epidemic

Enhances the body's

Prevent common flu 2007 disease system, priming caused by influenza the immune system to virus make antibodies against the flu virus

\author{
67
}


Table 2 (Contd.)

Characteristic vaccines

\begin{tabular}{lllll}
$\begin{array}{l}\text { S. } \\
\text { no. Generic name }\end{array}$ & Trade name & Type & Mode of action & \multicolumn{2}{c}{$\begin{array}{l}\text { Treatment for other } \\
\text { diseases }\end{array}$} & $\begin{array}{l}\text { Year of } \\
\text { approval }\end{array}$ \\
\hline $\begin{array}{l}60 \\
\begin{array}{l}\text { Influenza vaccine, split } \\
\text { virion, inactivated } \\
\text { hemagglutinin of A/ }\end{array}\end{array}$ & Anflu Sinovac & Split virion, inactivated & $\begin{array}{l}\text { Body generates } \\
\text { immuno-reactions } \\
\text { against influenza virus }\end{array}$ & $\begin{array}{l}\text { To prevent infection } \\
\text { caused by influenza } \\
\text { virus }\end{array}$
\end{tabular}
against influenza virus virus

California/7/2009

Hemagglutinin of A/

Victoria/210/2009

Hemagglutinin of $\mathrm{B} /$

Brisbane/60/2008

61 Rec hepatitis B vaccine Supervax

Hepatitis B vaccine, Active immunization of

immunoglobulin (HBIG) hepatitis B vaccine

To prevent infection

$2006 \quad 77$

induces the immune

against hepatitis $B$ virus

system to create anti-

HBs without an active

infection risk

62 Antirabies vaccine

63 Live herpes zoster vaccine

RABIRIX Bharath Biotech

Zostavax Merck

RotaTeq Bharath

Biotech

rotavirus $116 \mathrm{E}$ strain

derived in Vero cells

65 Human papillomavirus Gardasil, Cervarix Merck Protein subunit quadrivalent (type 6, 11, 16 , and 18) vaccine (HPV vaccine) J07BM01

66 Rotavirus vaccine with ROTARIX five strains of rotavirus, from both human and animal sources

67 Hepatitis B (r DNZ) Fendrix GSK vaccine, adjuvanted, absorbed J07BC01

68 MR vaccine freeze-dried, Mearubik, Mitsubishi live, attenuated, measles-rubella combined vaccine Tanabe Pharma

69 Inactivated hepatitis A Bilive Sinovac and hepatitis B (rDNA) $\mathrm{HAB}$ adsorbed vaccine

70 Virosomal influenza vaccine, Invivac influenza vaccine

71 Influenza virus (live) Flumist (LAIV), inactivated influenza vaccine (IIV)

72 Hepatitis A and B Vac DB10989, DB11627

Invivac Solvay

Pharmaceuticals

quadrivalent recombinant monovalent vaccine (PVRV) vaccine technology rubella technology

Adjuvant

Wild-type Corporation

Live, attenuated, oral

Live attenuated, oral,

Vero cell based rabies

Live attenuated virus

Inactivated virus vaccin boosts immunization against rabies

Enhancing VZV specific immunity against zoster

a neuropathic pain infants from the age of 6 rotavirus gastro-enteritis weeks

disease in infants and young children

Body's immune system To protect against either 2006 identifies the viral proteins in Gardasil, develops antibodies against them

Usually to develop immunity against two or four or nine types of HPV (cervical, vaginal and vulvar in females)

Rotarix vaccine assists to 2005 prevent this disease in rotavirus-based disease children

Adjuvanted, absorbed, recombinant DNA

Vaccine works by

Prevents hepatitis B 2005 priming the immune virus infection system

Live vaccine for measles, Immune system induced To prevent rubella virus 2005 to produce antibodies (proteins that fight and also kills the rubella virus)

Recombinant DNA Suboptimal immune Prevents hepatitis B viral 2005 response to the vaccine infection

The virosome

To treat influenza

2004

85 mechanism remains complex; it is the transporter as well as an immune stimulant Disease-causing viruses Protects against has been attenuated and infection from influenza inactivated, using the viruses influence of heat/ chemicals such as formaldehyde B-lymphocytes anti-HBs Immunization against 2003 


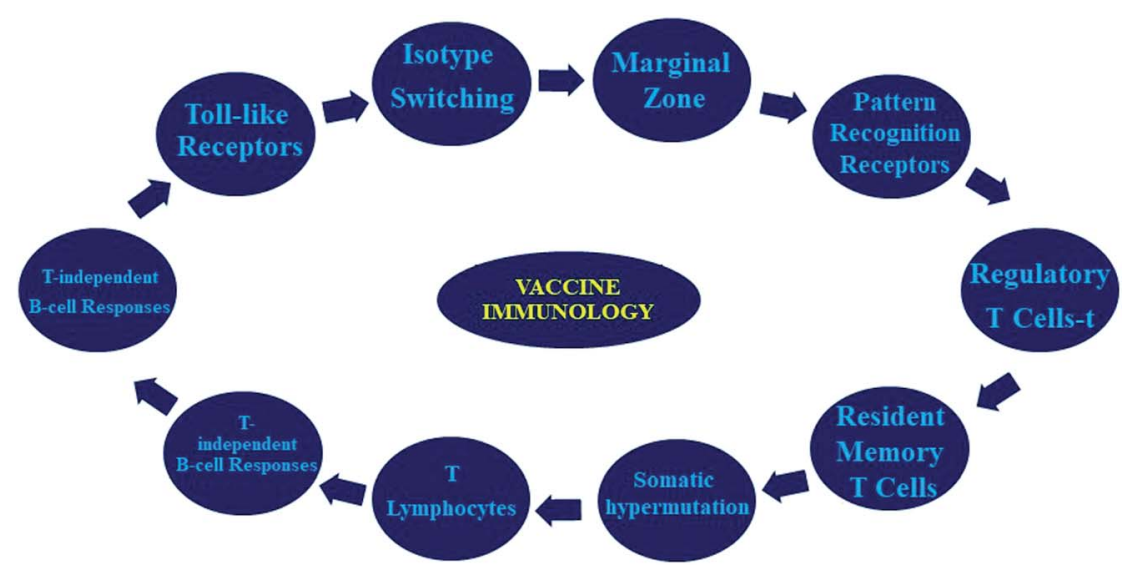

Fig. 2 General features of vaccine immunology.

immunoglobulin) at a particularly high rate throughout the proliferation of B-cells. This mechanistic process occurs as an effect of the cytidine deaminase enzyme and results in antibody diversification.

T lymphocytes. Cells that mature in the thymus, and become stimulated in the spleen or nodes if their T-cell receptors interact with an antigen marked with MHC molecules, and they obtain supplementary co-stimulation indications motivating them to kill the infected cell (mainly $\mathrm{CD} 8^{+} \mathrm{T}$ cells)/secondary (mainly $\mathrm{CD} 4^{+} \mathrm{T}$ cells) roles.

T-Independent B-cell responses. This B cell differentiation pathway is mostly triggered by polysaccharides, in the marginal zone and extra-follicular regions of the spleen or nodes. It provides a fast response (days), and generates transient (over months) low affinity antibodies without impacting immune memory.

T-Dependent B-cell responses. This B cell differentiation occurs due to protein antgens which recruit $\mathrm{T}$ and $\mathrm{B}$ cells into germinal centers of the spleen/nodes. It is slower (weeks), but provides enduring stimulation (years) with high affinity antibodies formation and immune memory.

Toll-like receptors. A cluster of 10 receptors (TLR1 to TLR10) existing at immune cell external regions, which identify pathogens and trigger characteristic immunity.

The main target of immunization through vaccination is to inhibit specific infections and their unavoidable difficulties. The best vaccine is the one which concomitantly accomplishes the following criteria such as:

(a) Actively inhibit the infective disease or else minimize the adverse effects of the disease;

(b) Offer a strong and continuing defence against a specific disease;

(c) Improves immunity through a minimum quantity of administrations;

(d) Deliver abundant antigens to afford wide-ranging safety against infection;

(e) Never results in side effects, or keeps them to a minimum;

(f) Remains stable under storage conditions, preferably mild storage conditions, for its shelf-life; (g) Can be produced on a huge scale;

(h) Should be economical and easily available.

Herein we consider the COVID-19 pandemic, the main resolution of vaccination against SARS-CoV-2 are:

(a) Inhibition of characteristic clinical symptoms so hospitalization is avoided, and reduces severe infectivity;

(b) Prevention of disease spreading before the corresponding antibodies are produced (sero conversion)

(c) Producing a strong neutralizing immune response able to link with the viral protein spike (S) that must prevent it from attaching to human cells.

From this perspective, the various immunological response effects which neutralize antibodies and $\mathrm{CD} 8^{+} \mathrm{T}$ cells are most significant.

The antibodies of anti-SARS-CoV-2 alert the host organism's immune response to the presence of the virus; such antibodies are immunoglobulins, which are appropriately split into IgA, IgM, IgG, and less frequently IgD. Prior serological antibody model responses to viral infections have usually proven the subsequent sequence of these antibodies resulting from virus infection: the antibodies of IgA are primary, which are followed by IgM, IgG-type continues at high levels for a longer time than the preceding ones (IgA and IgM). For certain viruses, sometimes the antigen (the virus itself) co-occurs with antibodies, particularly with the antibodies of primary IgA and IgM. Further, viruses have a "serological window," i.e., a period between the initial arrival of the antigen (in the blood) and the antibody response, thus phase intervals of infection occur. Eventually, IgG-type antibodies are specific to the novel coronavirus (SARS-CoV-2) and can be examined through chemiluminescence immunological routes, which is an automated laboratory process using enzyme-linked immunosorbent assays with higher arrangement. The examination mostly identifies the body's immune response to SARS CoV-2 infection.

\section{Significant characteristics of (corona) virus}

Before 2019, there were two pandemics caused in the past two decades by coronavirus; namely SARS during 2002-2003 and Middle East Respiratory Syndrome (MERS) in 2011. According 
to the International Committee on Taxonomy of Viruses (ICTV), the coronaviruses (CoVs) are sub-classified as Othocoronavirinae, which in turn consist of four categories - alpha-CoV, beta$\mathrm{CoV}$, gamma-CoV, and delta-CoV. The alpha- and beta-CoVs transmit disease in mammals such as bats, pigs, cats and mice. Gamma- and delta-CoVs usually infect birds. In addition, the seven different types of human CoVs - which include $\mathrm{HCoV}$ 229E, HCoV-NL63 - belong to alpha-CoVs. The HCoV-OC43, HCoV-HKU1, SARS-, MERS- CoVs, and the current pandemic SARS-CoV-2 belong to beta-CoVs, and the genus of such beta coronavirus occurrences are zoonotic infections. The December 2019 outbreak coronavirus, which leads to the respiratoryassociated syndrome, originated from Wuhan, China, and is called the novel corona virus disease 2019 or nCOVID-19, and its genome is fully sequenced. ${ }^{88}$ The genetic sequential arrangement of SARS-CoV-2 has an identical genomic array of SARS-/ MERS-CoV. ${ }^{89,90}$

Initially, the taxonomy of coronaviruses are split in to three groups, on account of genetic and serological interactions, the first set (Group-1) comprised several viruses including the porcine epidemic diarrhoea virus (PEDV), porcine transmissible gastroenteritis virus (TGEV), canine coronavirus (CCoV), feline infectious peritonitis virus (FIPV), the previously identified coronavirus of HCoV-229E, and HCoV-NL63. Whilst the second combination (Group-2) consists of murine hepatitis virus (MHV), bovine coronavirus (BCoV), human coronavirus OC43 (HCoV-OC43), rat sialodacryoadenitis virus (SDAV), porcine hemagglutinating encephalomyelitis virus (PHEV), canine respiratory coronavirus (CRCoV), and equine coronavirus (ECoV). In a similar pattern, the third group (Group-3) contains the avian infectious bronchitis virus (IBV) and Turkey coronavirus (TCoV). Now, the SARS coronaviruses (SARS-CoV) cannot be associated with any of these representative groups, however they possess some similarities along with the second group coronaviruses. $^{91 a}$

The battle between scientists and viral infections is a perpetual process and thus the identification of specific potential drugs with high efficiency and low toxicity is a continuous aim. Globally, this is the first time, that scientific researchers, diplomats, politicians, and capitalists have convened to work towards a common objective. The FDA approved drugs chloroquine and hydroxychloroquine to be utilized in critical illness cases, but clinical practices were still becoming overwhelmed by CoV cases. The suggestion to employ extensive use of these antiviral drugs was not sufficient. Certain polymerase nucleoside/nucleotide inhibitors are promising agents. Favipiravir a selective viral RdRp inhibitor, has been tested in clinical trials against COVID-19. Furthermore, the antiviral drugs lopinavir, ritonavir, remdesivir, nelfinavir, serine based protease inhibitors of nafamostat, camostat, efficient lipid reducing statin, rosovastatin, TNF alpha inhibitors, interleukin 1 receptor antagonists; Janus associated kinases (JAK) as well as monoclonal antibodies, tocilizumab, baricitinib and ruxolitinib etc., along with their combinations and other antiviral components, are also under investigation in clinical studies to combat COVID-19. In the future, researchers are requested to accumulate their results to provide more knowledge to repurpose significant drugs appropriately, and provide cheap drugs with the minimum toxicity profile. ${ }^{91 b, c}$

\section{The manufacture of SARS-CoV-2 vaccines through various approaches}

Vaccines have to be approved based on sufficient evidence. Many scientific researchers have reviewed the current literature and worked towards the development of a specific treatment for COVID-19. Current studies have exposed several beneficial opportunities, a few of them are more established and are in preclinical trials in addition to some in clinical trials. ${ }^{\mathbf{9 2 , 9 3}}$ Vaccines endeavor to represent the antibody to the antigen, and they should help the immune system (innate and adaptive immune responses, Fig. 3).

\section{Virus vaccines}

A number of vaccines are being developed for SARS-CoV-2, including inactivated and weakened, replicating and nonreplicating viral vectors, and the tentative use of nucleic acid in the form of DNA and RNA. Now, we can distinguish each vaccine characteristic as follows:

Weakened virus. Viruses cause disease by reproducing in a rapid manner. A weakened virus reproduces inside the human or animal host very poorly thereby decreasing its virulence and disease causing ability. One pharmaceutical company in the USA (Codagenix, New York) is collaborating with an Indian research team (Serum Institute at Pune) for the manufacture of SARS-CoV-2 with changed genetic sequence - making viral proteins with lower potency.

Inactivated virus. Chemicals such as formaldehyde, or thermal heating, are applied to inactivate a virus which is then used as a vaccine.

Viral-vector vaccines. In this technique other virus types are modified to render them safe and then used as a vaccine. They combine the qualities of DNA vaccines with those of live attenuated vaccines. The viral vector vaccine consists of a live attenuated virus which is genetically modified to carry the DNA encoding protein antigens from a different organism. For example, the virus belonging to measles/adenovirus is genetically modified and thus made safe. Currently there are products for veterinary use but not for human use. There are two types of viral vectors, ${ }^{94}$ one is still able to replicate inside the cells, while the other is non-replicating, since the key genes have been rendered inoperative.

Replicating viral vector (weakened measles). One of the approved Ebola vaccines is a typical paradigm for a viral-vector vaccine. Even if replication occurs inside cells, this vaccine is safe and will intensify the immune response.

Non-replicating viral vector (adenovirus variety). In general, viral vectors are genetically transformed to generate defective replications which are termed non-replicating vectors. Numerous viruses like adenovirus, adeno-linked, measles, and human parainfluenza viruses has been extensively utilized as viral vectors. Ultimately, the virus attains an attenuated state in which they can activate the anticipated human immune 


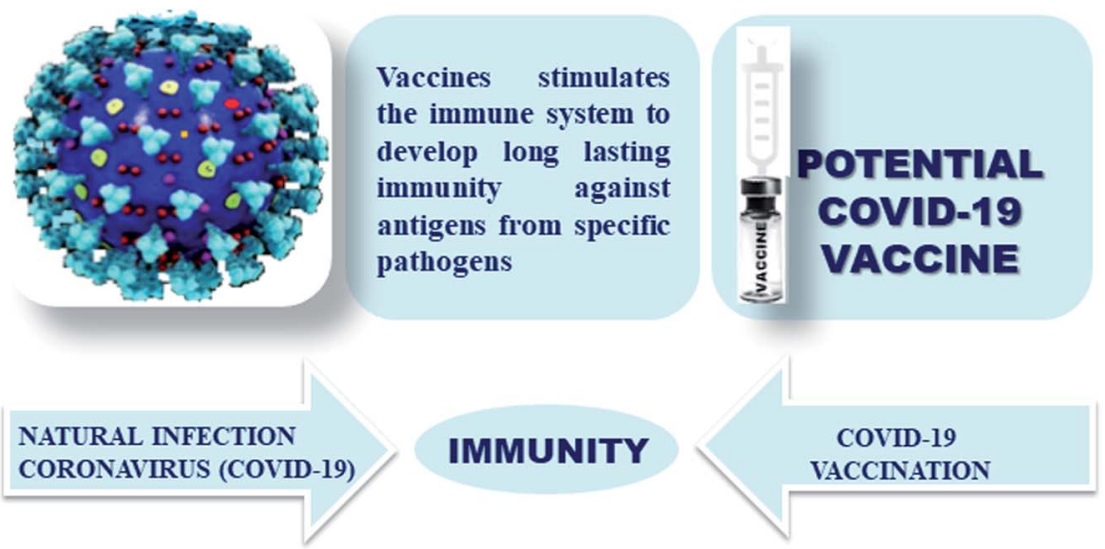

Immunization triggers an immune system response by which the vaccine develops longterm protection (immunity) that would normally follow recovery from (sometimes several) naturally occurring infections
Vaccine does not endure the illness, Low risk adverse reaction greatly outweighs the risk of complications by natural infection

Fig. 3 Pictorial representation of characteristic immunity.

responses, however, they are unable to reproduce in human cells.

Nucleic-acid vaccines. A number of groups are aspiring to utilize gene sequences (based on DNA or RNA) for a coronavirus protein to instantaneously provide an immune response. The majority of these vaccines focus on the spike protein present in the virus..$^{95}$

Protein-based vaccines. Several researchers have focused on injecting proteins present in coronavirus into the body. Also, protein fragments or shells of protein as copies of the coronavirus' surface could also be utilized.

Protein subunits. Nearly $28 \mathrm{t}$ groups are working on vaccines using subunits of viral proteins, predominantly on the spike protein at the receptor binding arena. Vaccines for protecting monkeys against SARS virus infection are available which have not been examined for humans. In fact, to employ such vaccines, adjuvant-immune-stimulation drug molecules should be administered together with the vaccine. ${ }^{96}$
Virus-like particles. Shells (outer regions) of an empty virus resemble the CoV structure, however, it is non-transmittable due to the absence of the genetic factors. Several research groups are engaged in vaccines based on virus-like particles that can activate a good immune response, however it is quite complex to synthesize such particles, and $70 \%$ of the teams directing their research in this way are from industry or private companies rather than academic laboratories. ${ }^{97,98}$

Table 3 and 4 provide a comprehensive overview of the current development of vaccines for SARS-CoV-2, their mode of action, their utility and the name of the manufacturer. ${ }^{99}$ More than 10 vaccines have almost reached the approval stage, while many are in the preclinical stage. Fig. 4 portrays the number of vaccine aspirants which are under clinical ( 63 drug aspirants) and preclinical ( $\sim 172$ drug aspirants) stages against nCOVID-19.99a Protein-based techniques seem to be the most popular among the various mechanisms (see https:/www.who.int/publications/ $\mathrm{m} /$ item/draft-landscape-of-covid-19-candidate-vaccines).
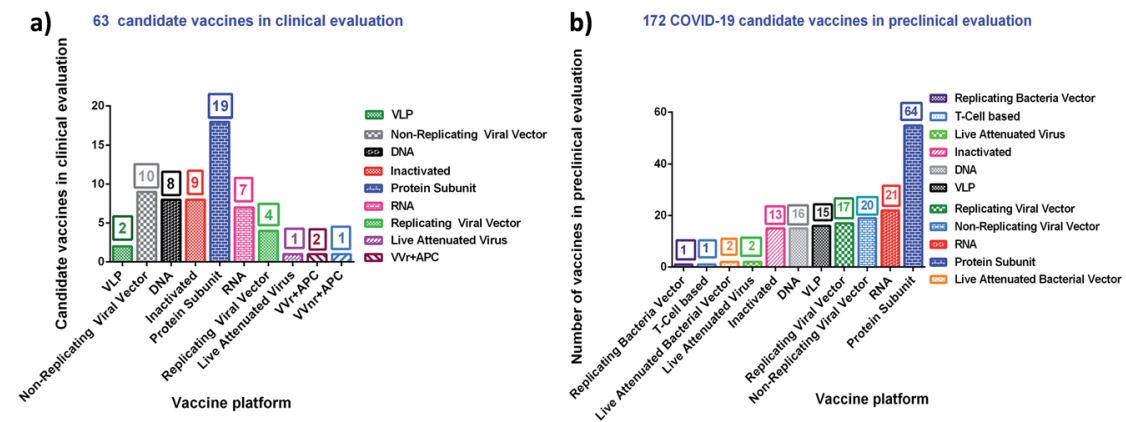

Fig. 4 nCOVID-19 vaccine aspirants at the clinical (63 drug aspirants) and preclinical (172 drug aspirants) stage. 
Table 3 COVID-19 aspirant developers and their significant details ${ }^{99 a} a$

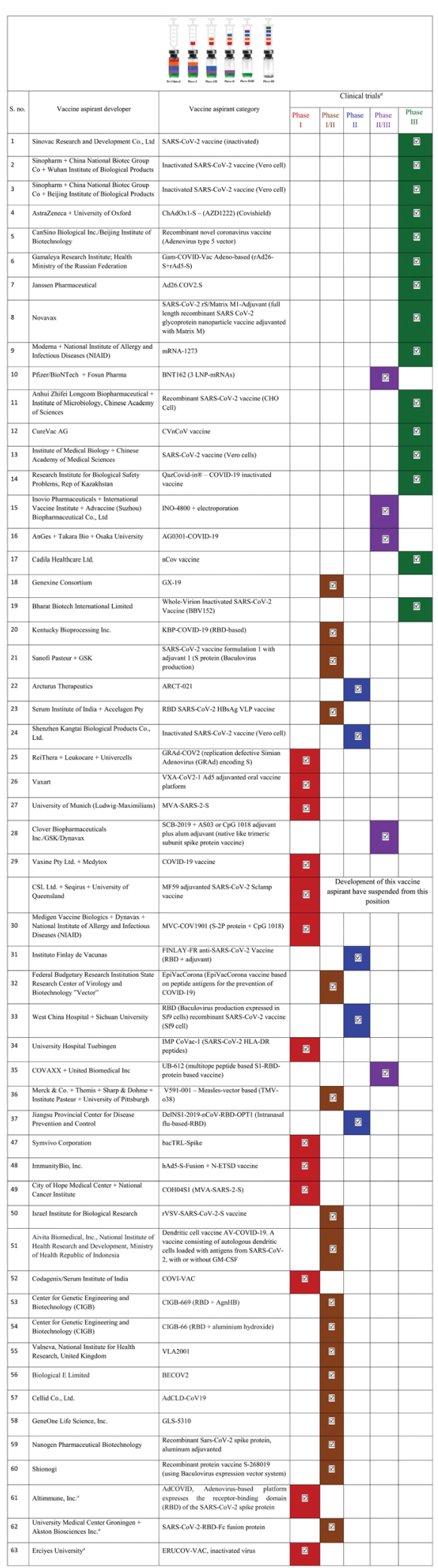

${ }^{a}$ Vaccine candidate list and relevant information shown according to the World Health Organization (WHO) statistical data for COVID-19 during 2019-2020. Clinical research data (last updated on January 08, 2021) may be variable.

\section{Comparison between previous vaccines and COVID-19} vaccines

Comparing COVID-19 vaccine novelty may seem challenging, but it is normal for queries to arise on a vaccine's overall potential, safety, toxicity and its side effects etc. ${ }^{100 a}$ and some of the efficacy, efficiency and safety of the COVID-19 frontrunner vaccines can be determined by comparison with other vaccines, like flu vaccines. For example, Pfizer/BioNTech released their COVID-19 vaccine initially in the UK and USA, and the rest of the world could see their effectiveness. However, prior to this demonstration the three prominent COVID-19 vaccines - Pfizer/ BioNTech claims an efficacy of 95\%, the Oxford/AstraZeneca provides $70 \%$, and the Moderna is stated as $94.1 \%$ efficacy were compared with other available vaccines such as the flu, polio, and measles, which helped provide their effectiveness and efficiency predictions.

It is important to discuss here that "effectiveness" and "efficacy" are different. ${ }^{\mathbf{1 0 0 b}}$ Efficacy states how a vaccine performs in ideal lab circumstances, like those present in clinical trials. Whereas, effectiveness means how the vaccine works in normal, non-controlled conditions. For example, in a clinical trial, $90 \%$ efficacy refers to $90 \%$ lower disease rates in the group getting the vaccine compared with the sample group. But, the members in a group selected for a clinical trial have to be in good health and young and they usually have no underlying health conditions. Besides, medical researchers will not generally consider some demographics in these clinical research studies like children/pregnant women. Thus, once a vaccine is able to prevent disease in clinical trials, we may observe the effectiveness drop when directed to different demographics.

Vaccines do not necessarily need high effectiveness to protect several thousands of lives from disease. For instance, the vaccine for $\mathrm{flu}^{\mathbf{1 0 0}}$ has $40-60 \%$ effectiveness according to CDC data. During 2018-19, this vaccine prevented millions of influenza cases and its associated illness, but determining the exact effectiveness rate is challenging. Dosages can also increase effectiveness for some vaccines. The two doses of a vaccine can give a protection boost, nevertheless this advantage is sometimes limited to only certain groups like children/ organ transplanted people. The booster dosage may not provide an advantage in people aged 65 years.

Through comparing vaccines, like the ones for polio and measles, we see heavy dosages are needed to realize effectiveness.

Polio vaccines ${ }^{\mathbf{1 0 0}}$ should be up to $100 \%$ effective. According to the CDC, "Two inactivated polio vaccine (IPV) dosages have 90\% effectiveness; three dosages are 99-100\% effective." The IPV vaccine prevents poliomyelitis (poliovirus), which can activate infection in the brain and spinal cord leading to paralysis.

The MMR vaccine ${ }^{\mathbf{1 0 0 e}}$ defends against measles, mumps, and rubella, which tends to have up to $97 \%$ effectiveness at inhibiting measles once directed in two dosages. A single dose is around $93 \%$ effective, as reported by the CDC. They suggest to give the initial dose at "12-15 months of age, followed by the second dose at 4-6 years." 
Table 4 Range of SARS-CoV-2 vaccine aspirants and their representative data ${ }^{16 a, b, 99 c}$

\begin{tabular}{|c|c|c|c|c|c|c|c|c|}
\hline ID & $\begin{array}{l}\text { Vaccine } \\
\text { division } \\
\text { acronym }\end{array}$ & $\begin{array}{l}\text { Vaccine sector } \\
\text { description }\end{array}$ & $\begin{array}{l}\text { Vaccine category } \\
\text { and composition }\end{array}$ & $\begin{array}{l}\text { Characteristic } \\
\text { nature of } \\
\text { vaccination }\end{array}$ & Producers & Clinical phases & $\begin{array}{l}\text { Vaccine utility } \\
\text { for other viruses }\end{array}$ & Ref. \\
\hline 1 & IV & Inactivated virus & $\begin{array}{l}\text { Vaccines of } \\
\text { CoronaVac, } \\
\text { PiCoVaccine, } \\
\text { based on vaccine } \\
\text { cultured in Vero } \\
\text { cells, inactivated } \\
\text { pathogen }\end{array}$ & $\begin{array}{l}\text { Based on an } \\
\text { inactivated } \\
\text { pathogen, body } \\
\text { generates a varied } \\
\text { immune response } \\
\text { against several viral } \\
\text { antigens, producing } \\
\text { neutralizing } \\
\text { antibodies }\end{array}$ & Sinovac R\&D Co. Ltd & $\begin{array}{l}\text { Phase III NCT04456595, Phase } \\
\text { 1/2 NCT04383574, } \\
\text { NCT04352608 }\end{array}$ & $\begin{array}{l}\text { Vaccine being } \\
\text { developed for } \\
\text { treatment of } \\
\text { SARS-CoV-2 }\end{array}$ & 101 \\
\hline 2 & IV & Inactivated virus & $\begin{array}{l}\text { Inactivated } \\
\text { vaccine, Vero cell } \\
\text { based }\end{array}$ & $\begin{array}{l}\text { Vaccine from non- } \\
\text { living viral particles, } \\
\text { bacteria, and other } \\
\text { pathogens which are } \\
\text { developed in } \\
\text { a culture medium. } \\
\text { No potential for } \\
\text { infection, but } \\
\text { induces an immune } \\
\text { system response }\end{array}$ & Sinopharm + WIBP & $\begin{array}{l}\text { Phase 3, Phase-I/II/III } \\
\text { ChiCTR2000031809 }\end{array}$ & $\begin{array}{l}\text { Vaccine being } \\
\text { developed for } \\
\text { treatment of } \\
\text { SARS-CoV-2 }\end{array}$ & 102 \\
\hline 3 & IV & Inactivated virus & $\begin{array}{l}\text { Inactivated and } \\
\text { similar to virus } \\
\text { vaccine based on } \\
\text { Vero cells }\end{array}$ & $\begin{array}{l}\text { The foremost } \\
\text { vaccine, does not } \\
\text { exhibit any adverse } \\
\text { side effects with } \\
\text { favored } \\
\text { immunogenicity and } \\
\text { safety; also an } \\
\text { inactivated new } \\
\text { crown vaccine which } \\
\text { completely } \\
\text { neutralizes the } \\
\text { antibodies in } 28 \text { days }\end{array}$ & Sinopharm + BIBP & Phase 3 ChiCTR2000032459 & $\begin{array}{l}\text { Vaccine being } \\
\text { developed for } \\
\text { treatment of } \\
\text { similar viruses }\end{array}$ & $92 d$ \\
\hline 4 & VVnr & $\begin{array}{l}\text { Viral vector (non- } \\
\text { replicating) }\end{array}$ & $\begin{array}{l}\text { Covishield } \\
\text { ChAdOx1-S- } \\
\text { (AZD1222) }\end{array}$ & $\begin{array}{l}\text { Adenovirus vector } \\
\text { based on } \\
\text { chimpanzee } \\
\text { adenovirus }\end{array}$ & $\begin{array}{l}\text { AstraZeneca + Oxford } \\
\text { University }\end{array}$ & $\begin{array}{l}\text { Phase } 3 \text { ISRCTN89951424, } \\
\text { Phase } 2 \text { b/3 2020-001228-32, } \\
\text { Phase } 1 / 2 \\
\text { PACTR2020069221651322020- } \\
001072-15\end{array}$ & $\begin{array}{l}\text { MERS, influenza, } \\
\text { TB, } \\
\text { Chikungunya, } \\
\text { Zika, MenB, } \\
\text { plague }\end{array}$ & 103 \\
\hline 5 & VVnr & $\begin{array}{l}\text { Viral vector (non- } \\
\text { replicating) }\end{array}$ & $\begin{array}{l}\text { Ad5-nCoV } \\
\text { recombinant } \\
\text { vaccine for } \mathrm{CoV}\end{array}$ & $\begin{array}{l}\text { Recombinant } \\
\text { adenovirus type } 5 \\
\text { vector based vaccine } \\
\text { aspirant, which is } \\
\text { genetically modified } \\
\text { with replication- } \\
\text { deficient groups, } \\
\text { mimics SARS-CoV-2 } \\
\text { spike protein }\end{array}$ & $\begin{array}{l}\text { Beijing } \\
\text { Biotechnology } \\
\text { Institute/CanSino } \\
\text { Biological Inc. }\end{array}$ & $\begin{array}{l}\text { Phase } 2 \text { ChiCTR2000031781, } \\
\text { Phase } 1 \text { ChiCTR2000030906 }\end{array}$ & $\begin{array}{l}\text { EBOV (Ebola } \\
\text { virus) }\end{array}$ & 104 \\
\hline 6 & VVnr & $\begin{array}{l}\text { Viral vector (non- } \\
\text { replicating) }\end{array}$ & $\begin{array}{l}\text { Gam-COVID-Vac } \\
\text { adeno-based } \\
\text { (rad26-S+rAd5-S), } \\
\text { Russian COVID- } \\
19 \text { vaccine, } \\
\text { adenovirus } \\
\text { based, and non- } \\
\text { replicating }\end{array}$ & $\begin{array}{l}\text { Develop immunity } \\
\text { against the } \\
\text { coronavirus, and } \\
\text { strengthens the } \\
\text { immune system }\end{array}$ & $\begin{array}{l}\text { Gamaleya Research } \\
\text { Institute; Ministry of } \\
\text { Health, Russian } \\
\text { Federation }\end{array}$ & $\begin{array}{l}\text { Phase-I/III NCT04436471, } \\
\text { NCT04437875 }\end{array}$ & $\begin{array}{l}\text { Vaccine being } \\
\text { developed for } \\
\text { treatment of } \\
\text { SARS-CoV-2 }\end{array}$ & 105 \\
\hline 7 & VVnr & $\begin{array}{l}\text { Viral vector (non- } \\
\text { replicating) }\end{array}$ & $\begin{array}{l}\text { Ad26.COV2.S } \\
\text { recombinant } \\
\text { serotype } 26, \\
\text { adenovirus } \\
\text { vectors, } \\
\text { multivalent } \\
\text { vaccine }\end{array}$ & $\begin{array}{l}\text { Activates specific } \\
\text { acquired immunity } \\
\text { for Ebola virus }\end{array}$ & $\begin{array}{l}\text { Janssen } \\
\text { Pharmaceutical }\end{array}$ & $\begin{array}{l}\text { Phase } 3 \text { NCT04505722, } \\
\text { NCT04614948 }\end{array}$ & $\begin{array}{l}\text { Vaccine being } \\
\text { developed for } \\
\text { treatment of } \\
\text { similar viruses }\end{array}$ & 106 \\
\hline
\end{tabular}


Table 4 (Contd.)

\begin{tabular}{|c|c|c|c|c|c|c|c|c|}
\hline ID & $\begin{array}{l}\text { Vaccine } \\
\text { division } \\
\text { acronym }\end{array}$ & $\begin{array}{l}\text { Vaccine sector } \\
\text { description }\end{array}$ & $\begin{array}{l}\text { Vaccine category } \\
\text { and composition }\end{array}$ & $\begin{array}{l}\text { Characteristic } \\
\text { nature of } \\
\text { vaccination }\end{array}$ & Producers & Clinical phases & $\begin{array}{l}\text { Vaccine utility } \\
\text { for other viruses }\end{array}$ & Ref. \\
\hline 8 & PS & Protein subunit & $\begin{array}{l}\text { SARS-CoV-2 rS/ } \\
\text { Matrix M1- } \\
\text { adjuvant (full } \\
\text { size recombinant } \\
\text { SARS CoV-2 GP } \\
\text { nanoparticle } \\
\text { based vaccine } \\
\text { with Matrix Mas } \\
\text { adjuvant) }\end{array}$ & $\begin{array}{l}\text { Matrix-M, an } \\
\text { adjuvant which } \\
\text { improves the } \\
\text { immune response } \\
\text { and induces } \\
\text { advanced } \\
\text { neutralizing } \\
\text { antibodies }\end{array}$ & Novavax & $\begin{array}{l}\text { Phase } 3 \text { NCT04611802, } \\
\text { NCT04583995 }\end{array}$ & $\begin{array}{l}\text { Ebola, Lassa, } \\
\text { MERS, Nipah, } \\
\text { Rift Valley Fever } \\
\text { and } \\
\text { Chikungunya }\end{array}$ & 107 \\
\hline 9 & RNA & $\begin{array}{l}\text { RNA based } \\
\text { vaccine }\end{array}$ & $\begin{array}{l}\text { Moderna mRNA- } \\
1273 \text { vaccine, } \\
\text { LNP } \\
\text { encapsulated cell } \\
\text { bank; mRNA, } \\
\text { VAX (non- } \\
\text { replicating viral } \\
\text { vector) }\end{array}$ & $\begin{array}{l}\text { A vaccine with } \\
\text { mRNA encapsulated } \\
\text { in LNP, encoding for } \\
\text { perfusion stabilized } \\
\text { spike (S) protein. } \\
\text { Host generates an } \\
\text { immune response } \\
\text { against the spike } \\
\text { protein on SARS- } \\
\text { CoV-2 }\end{array}$ & Moderna + NIAID & $\begin{array}{l}\text { Phase } 3 \text { NCT0 } 4470427 \text {, Phase } \\
2 \text { NCT0 } 4405076 \text {, Phase } 1 \\
\text { NCT0 } 4283461\end{array}$ & Multiple agents & 108 \\
\hline 10 & RNA & $\begin{array}{l}\text { mRNA based } \\
\text { vaccine }\end{array}$ & $\begin{array}{l}\text { BNT162 (3 LNP- } \\
\text { mRNAs) }\end{array}$ & $\begin{array}{l}\text { BNT162 contains } \\
\text { a nucleoside } \\
\text { modified mRNA } \\
\text { (modRNA) encoding } \\
\text { the viral spike (S) } \\
\text { glycoprotein }\end{array}$ & $\begin{array}{l}\text { BioNTech + Fosun } \\
\text { Pharma; Jiangsu } \\
\text { Provincial CDC + } \\
\text { Pfizer }\end{array}$ & Phase $2 / 3$ NCT04368728 & $\begin{array}{l}\text { To be } \\
\text { implemented }\end{array}$ & 109 \\
\hline 11 & PS & Protein subunit & $\begin{array}{l}\text { Recombinant } \\
\text { COVID-19 } \\
\text { vaccine, CHO } \\
\text { (Chinese } \\
\text { hamster ovary) } \\
\text { cell system, } \\
\text { prevents CoVs }\end{array}$ & $\begin{array}{l}\text { Increases rate of new } \\
\text { coronavirus } \\
\text { neutralizing S } \\
\text { protein antibody } \\
\text { (IgG) and RBD } \\
\text { protein antibody } \\
\text { (IgG) }\end{array}$ & $\begin{array}{l}\text { Anhui Zhifei } \\
\text { Longcom } \\
\text { Biopharmaceutical + } \\
\text { IMCAS }\end{array}$ & $\begin{array}{l}\text { Phase-I NCT04453852, } \\
\text { NCTo4445194, Phase } 3 \\
\text { NCT04646590 }\end{array}$ & $\begin{array}{l}\text { Vaccine being } \\
\text { developed for } \\
\text { treatment of } \\
\text { SARS-CoV-2 }\end{array}$ & 110 \\
\hline 12 & RNA & $\begin{array}{l}\text { mRNA based } \\
\text { vaccine }\end{array}$ & CVnCoV vaccine & $\begin{array}{l}\text { Nucleotides without } \\
\text { chemical } \\
\text { modifications in the } \\
\text { mRNA }\end{array}$ & CureVac AG & $\begin{array}{l}\text { NCT04449276 Phase } 1, \\
\text { NCT04515147 Phase } 2, \\
\text { NCT04674189 Phase } 3\end{array}$ & $\begin{array}{l}\text { CureVac's } \\
\text { vaccine } \\
\text { candidate } \\
\text { against SARS- } \\
\text { CoV-2 }\end{array}$ & 111 \\
\hline 13 & IV & Inactivated virus & $\begin{array}{l}\text { Vaccine for SARS- } \\
\text { CoV-2 based on } \\
\text { Vero cells }\end{array}$ & $\begin{array}{l}\text { ELISA derived } \\
\text { antibodies (IgGs) } \\
\text { and neutralizing } \\
\text { antibodies, target } \\
\text { the spike protein, N } \\
\text { protein virion and } \\
\text { the specific positive } \\
\text { CTL responses } \\
\text { against N, S and } \\
\text { virion antigens }\end{array}$ & $\mathrm{IMB}+\mathrm{CAMS}$ & $\begin{array}{l}\text { Phase } 3 \text { NCT04659239, Phase } \\
\text { 1/2 NCT04470609, } \\
\text { NCT04412538 }\end{array}$ & $\begin{array}{l}\text { To be } \\
\text { implemented }\end{array}$ & 112 \\
\hline 14 & IV & Inactivated virus & $\begin{array}{l}\text { QazCovid-in } ®- \\
\text { COVID-19 } \\
\text { inactivated } \\
\text { vaccine }\end{array}$ & $\begin{array}{l}\text { There are specific } \\
\text { antibodies that } \\
\text { activate upon } \\
\text { receiving small } \\
\text { dilutions given in } \\
\text { the vaccine, they } \\
\text { constantly } \\
\text { counterbalance the } \\
\text { novel coronavirus } \\
\text { with a virulence dose } \\
\text { of } 3000 \text { TCD50 }\end{array}$ & $\begin{array}{l}\text { RIBSP, Republic of } \\
\text { Kazakhstan }\end{array}$ & Phase 1/2 NCT04530357 & $\begin{array}{l}\text { Vaccine being } \\
\text { developed for } \\
\text { treatment of } \\
\text { SARS-CoV-2 }\end{array}$ & 113 \\
\hline
\end{tabular}


Table 4 (Contd.)

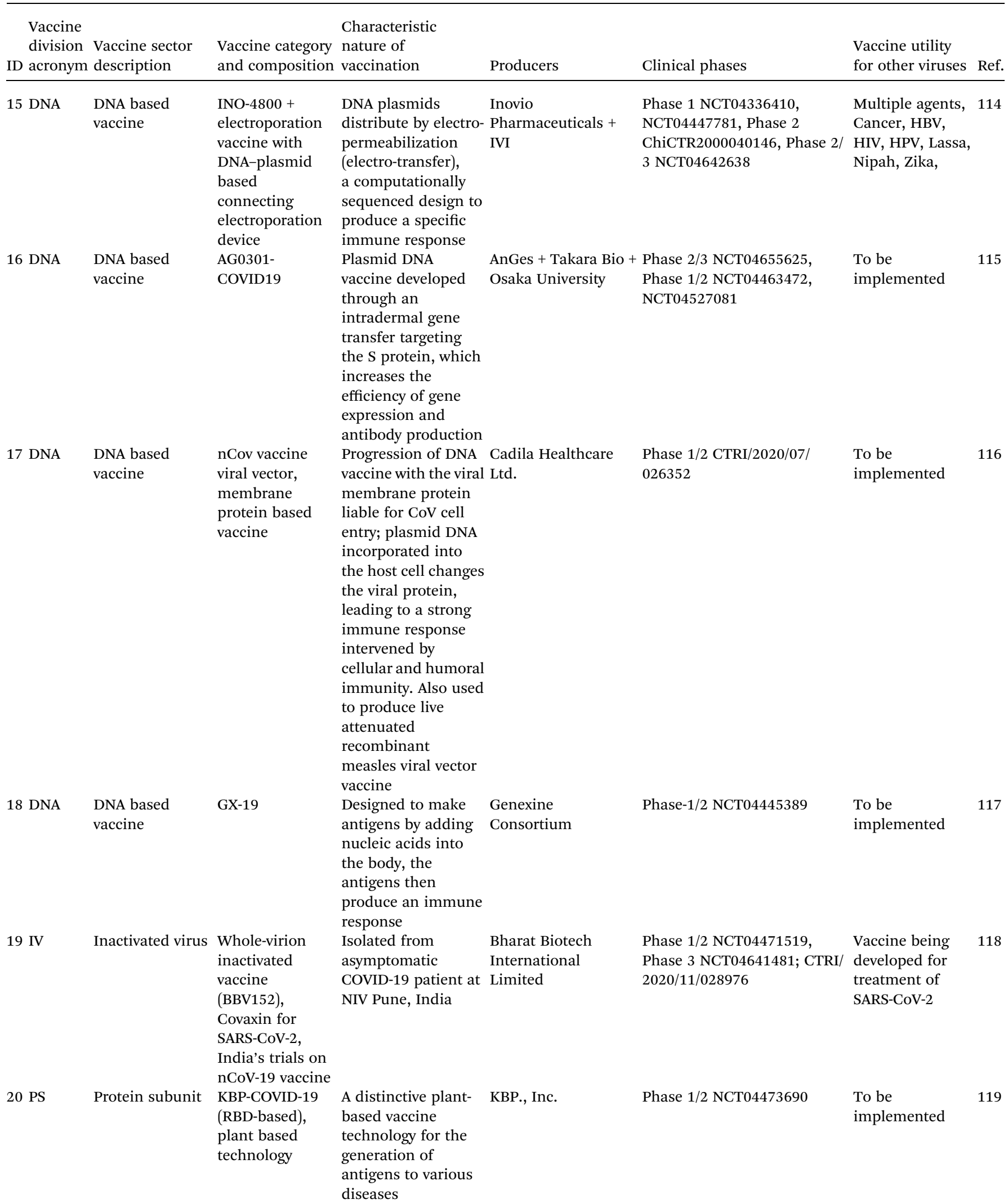


Table 4 (Contd.)

\begin{tabular}{|c|c|c|c|c|c|c|c|}
\hline $\begin{array}{c}\text { Vaccine } \\
\text { division } \\
\text { ID acronym }\end{array}$ & $\begin{array}{l}\text { Vaccine sector } \\
\text { description }\end{array}$ & $\begin{array}{l}\text { Vaccine category } \\
\text { and composition }\end{array}$ & $\begin{array}{l}\text { Characteristic } \\
\text { nature of } \\
\text { vaccination }\end{array}$ & Producers & Clinical phases & $\begin{array}{l}\text { Vaccine utility } \\
\text { for other viruses }\end{array}$ & Ref. \\
\hline $21 \mathrm{PS}$ & Protein subunit & $\begin{array}{l}\text { Adjuvanted } \\
\text { vaccine of SARS- } \\
\text { CoV-2 } \\
\text { formulation } \\
\text { spike protein } \\
\text { (baculovirus } \\
\text { production) }\end{array}$ & - & $\begin{array}{l}\text { Sanofi Pasteur + } \\
\text { Glaxo SmithKline } \\
\text { plc. }\end{array}$ & Phase $1 / 2$ NCT04537208 & & 120 \\
\hline 22 RNA & $\begin{array}{l}\text { RNA based } \\
\text { vaccine }\end{array}$ & ARCT-021 & $\begin{array}{l}\text { Powerful single } \\
\text { dose, vaccine is } \\
\text { based upon self- } \\
\text { replicating mRNA, } \\
\text { self-transcribing and } \\
\text { replicating RNA } \\
\text { along with its liquid- } \\
\text { enabling and } \\
\text { resolving nucleo- } \\
\text { monomer facilitator } \\
\text { altered RNA }\end{array}$ & $\begin{array}{l}\text { Arcturus } \\
\text { Therapeutics }\end{array}$ & Phase $1 / 2$ NCT0448095 & $\begin{array}{l}\text { Vaccine being } \\
\text { developed for } \\
\text { treatment of } \\
\text { SARS-CoV-2 }\end{array}$ & 121 \\
\hline 23 VLP & $\begin{array}{l}\text { Virus like } \\
\text { particle }\end{array}$ & $\begin{array}{l}\text { RBD SARS-CoV-2 } \\
\text { HBsAg VLP } \\
\text { vaccine }\end{array}$ & $\begin{array}{l}\text { Neutralizing } \\
\text { antibodies response } \\
\text { in pigs, treated } \\
\text { together with } \\
\text { pseudo type } \\
\text { lentivirus and live } \\
\text { SARS-CoV-2 viruses. } \\
\text { Immunoglobulin } \\
\text { (IgG) response } \\
\text { observed after } \\
\text { booster } \\
\text { immunization }\end{array}$ & SII + Accelagen Pty & $\begin{array}{l}\text { Phase } 1 / 2 \\
\text { ACTRN12620000817943 }\end{array}$ & $\begin{array}{l}\text { Vaccine being } \\
\text { developed for } \\
\text { treatment of } \\
\text { SARS-CoV-2 }\end{array}$ & 122 \\
\hline $\begin{array}{c}24 \mathrm{VVnr}+ \\
\mathrm{APC}\end{array}$ & $\begin{array}{l}\text { Viral vector (non- } \\
\text { replicating) }+ \\
\text { APC IV } \\
\text { inactivated virus }\end{array}$ & $\begin{array}{l}\text { SARS-CoV-2 } \\
\text { vaccine } \\
\text { (inactivated) }\end{array}$ & & $\begin{array}{l}\text { Shenzhen Geno- } \\
\text { Immune Medical } \\
\text { Institute }\end{array}$ & Phase 1/2 NCT04276896 & $\begin{array}{l}\text { Vaccine for SARS- } \\
\text { CoV-2 }\end{array}$ & 123 \\
\hline $25 \mathrm{VVnr}$ & $\begin{array}{l}\text { Viral vector (non- } \\
\text { replicating) }\end{array}$ & $\begin{array}{l}\text { GRAd-COV2 } \\
\text { replication using } \\
\text { defective simian } \\
\text { adenoviral vector } \\
\text { (GRAd), encodes } \\
\text { full length CoV } \\
\text { spike protein }\end{array}$ & $\begin{array}{l}\text { Able to generate } \\
\text { immune response } \\
\text { (antibodies and } \mathrm{T} \\
\text { cells) }\end{array}$ & $\begin{array}{l}\text { ReiThera + } \\
\text { Leukocare + } \\
\text { Univercells }\end{array}$ & Phase 2 ChiCTR2000039462 & $\begin{array}{l}\text { Ebola and RSV } \\
\text { (respiratory } \\
\text { syncytial virus) }\end{array}$ & 124 \\
\hline $26 \mathrm{VVnr}$ & $\begin{array}{l}\text { Viral vector (non- } \\
\text { replicating) }\end{array}$ & $\begin{array}{l}\text { VXA-CoV2-1 Ad5 } \\
\text { adjuvanted oral } \\
\text { vaccine platform }\end{array}$ & $\begin{array}{l}\text { Vaccine mainly } \\
\text { provides mucosal } \\
\text { immunity, this vital } \\
\text { factor targets } \\
\text { mucosal pathogens, } \\
\text { including the } \\
\text { current coronavirus. } \\
\text { Stimulates antigen- } \\
\text { specific CD4 }{ }^{+} \text {and } \\
\text { CD8 }{ }^{+} \text {T cells at low } \\
\text { and high dosage } \\
\text { levels }\end{array}$ & Vaxart & Phase 1 NCT04563702 & $\begin{array}{l}\text { Influenza } \\
\text { infection H1N1 }\end{array}$ & 125 \\
\hline
\end{tabular}


Table 4 (Contd.)

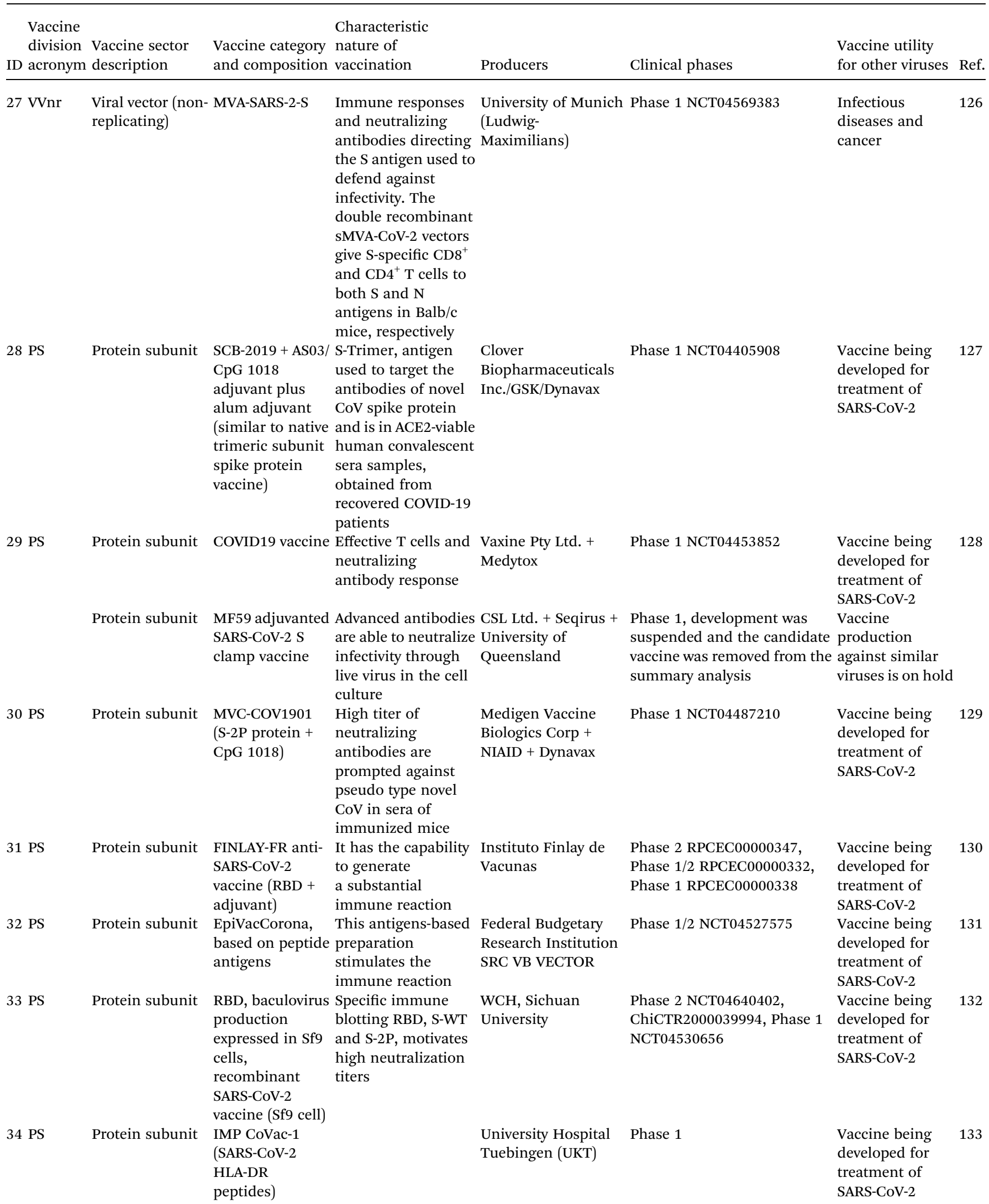


Table 4 (Contd.)

\begin{tabular}{ll}
\multicolumn{2}{c}{$\begin{array}{l}\text { Vaccine } \\
\text { division }\end{array}$} \\
ID accine sector \\
\hline $35 \mathrm{PS}$ & Protein subunit \\
$36 \mathrm{VVr} \quad \begin{array}{l}\text { Viral vector } \\
\text { (replicating) }\end{array}$
\end{tabular}

\section{$37 \mathrm{VVr} \quad$ Viral vector} (replicating)

\section{RNA \\ RNA based} vaccine

40 VLP

Virus-like particle

\section{$41 \mathrm{VVr}+\quad$ Viral vector APC (replicating) + APC}

\section{Characteristic}

Vaccine category nature of and composition vaccination

Producers peptide based S1- to reduce future RBD-protein pandemic rates based vaccine V591-001- Attains the target Merck \& Co., measles-vector immune response in Themis + Sharp \& based (TMV-o38) humans

Dohme + Pasteur Institute + Pittsburgh

\section{DelNS1-2019- \\ SARS-CoV-2 RBD Jiangsu Provincial} University

nCoV-RBD- protein based CDC flu-based-RBD

motivate crossreactivity or crossneutralizing antibodies; moreover it blocks previous $\mathrm{CoV}$ pseudovirus and the advanced novel $\mathrm{CoV}$ pseudovirus into hACE2 expressing $293 \mathrm{~T}$ cells $\left(\mathrm{IC}_{50}=\right.$ 4.1 and $11.63 \mu \mathrm{g}$ $\mathrm{ml}^{-1}$ ) can activate a strong London immune response; it is suggested that the IM vaccination antigen is expressed in muscle cells, then moves to antigen presenting cells (APC), representing a cross priming mode of potentiality to prominent $\mathrm{CD}^{+} \mathrm{T}$ cells SARS-CoV-2 -
mRNA vaccine

Coronavirus-like Provides immunity particle COVID- by generating 19 (CoVLP) a harmless spike protein member, reduces severe infection effects

COVID-19/aAPC Artificial antigenvaccine pathogen-specific produced from a variation of lentivirus with immune modulatory vaccine, which uses the spike protein binding to the ACE2 receptor; the vaccine utilizes the modified genes and viral minigenes to direct minigenes to the viral proteins, vary aAPCs aAPC, and trigger Tcells
Shulan (Hangzhou) Phase 1

Hospital and CDC at

Guangxi Zhuang

Autonomous Region

Medicago Inc.

Phase $2 / 3$
Shenzhen

Genoimmune

Phase 1 NCT04299724

Medical Institute
Clinical phases

Phase 1 ISRCTN17072692 developed for treatment of SARS-CoV-2 
Table 4 (Contd.)

\begin{tabular}{|c|c|c|c|c|c|c|c|}
\hline $\begin{array}{r}\text { Vaccine } \\
\text { division } \\
\text { ID acronym }\end{array}$ & $\begin{array}{l}\text { Vaccine sector } \\
\text { description }\end{array}$ & $\begin{array}{l}\text { Vaccine category } \\
\text { and composition }\end{array}$ & $\begin{array}{l}\text { Characteristic } \\
\text { nature of } \\
\text { vaccination }\end{array}$ & Producers & Clinical phases & $\begin{array}{l}\text { Vaccine utility } \\
\text { for other viruses }\end{array}$ & Ref. \\
\hline 43 PS & Protein subunit & $\begin{array}{l}\text { AdimrSC-2f } \\
\text { (recombinant } \\
\text { RBD } \pm \\
\text { aluminium) }\end{array}$ & - & $\begin{array}{l}\text { Adimmune } \\
\text { Corporation }\end{array}$ & Phase 1 NCT04522089 & $\begin{array}{l}\text { Vaccine being } \\
\text { developed for } \\
\text { treatment of } \\
\text { SARS-CoV-2 }\end{array}$ & 142 \\
\hline 44 DNA & $\begin{array}{l}\text { DNA based } \\
\text { vaccine }\end{array}$ & $\begin{array}{l}\text { Covigenix VAX- } \\
001\end{array}$ & $\begin{array}{l}\text { Induces neutralizing } \\
\text { antibody levels and } \\
\text { stable T helper cell } \\
\text { immunity }\end{array}$ & $\begin{array}{l}\text { Entos } \\
\text { Pharmaceuticals Inc. }\end{array}$ & Phase 1 NCT04591184 & $\begin{array}{l}\text { Vaccine being } \\
\text { developed for } \\
\text { treatment of } \\
\text { SARS-CoV-2 }\end{array}$ & 143 \\
\hline 45 DNA & $\begin{array}{l}\text { DNA based } \\
\text { vaccine }\end{array}$ & CORVax & $\begin{array}{l}\text { CORVax12 initiates } \\
\text { a coordinated } \\
\text { vaccine response, } \\
\text { able to expose the } \\
\text { innate adaptive } \\
\text { humoral and cellular } \\
\text { arms. These cellular } \\
\text { immune responses } \\
\text { have the potential to } \\
\text { generate a strong } \\
\text { antiviral response }\end{array}$ & $\begin{array}{l}\text { Providence Health \& } \\
\text { Services }\end{array}$ & Phase 1 NCT04627675 & $\begin{array}{l}\text { Vaccine being } \\
\text { developed for } \\
\text { treatment of } \\
\text { similar viruses }\end{array}$ & 144 \\
\hline 46 RNA & $\begin{array}{l}\text { RNA based } \\
\text { vaccine }\end{array}$ & $\begin{array}{l}\text { ChulaCov19 } \\
\text { mRNA vaccine }\end{array}$ & $\begin{array}{l}\text { The mRNA based } \\
\text { vaccine encodes } \\
\text { a protein antigen, } \\
\text { while RNA is } \\
\text { considered to be } \\
\text { unstable; the design } \\
\text { and development of } \\
\text { this novel vaccine is } \\
\text { improving its } \\
\text { constancy and } \\
\text { protein translation } \\
\text { efficacy, so it } \\
\text { efficiently enhances } \\
\text { immune response }\end{array}$ & $\begin{array}{l}\text { Chulalongkorn } \\
\text { University }\end{array}$ & Phase 1 NCT04566276 & $\begin{array}{l}\text { Vaccine being } \\
\text { developed for } \\
\text { treatment of } \\
\text { similar viruses }\end{array}$ & 145 \\
\hline
\end{tabular}


Table 4 (Contd.)

\begin{tabular}{|c|c|c|c|c|c|c|c|}
\hline $\begin{array}{r}\text { Vaccine } \\
\text { division } \\
\text { ID acronym }\end{array}$ & $\begin{array}{l}\text { Vaccine sector } \\
\text { description }\end{array}$ & $\begin{array}{l}\text { Vaccine category } \\
\text { and composition }\end{array}$ & $\begin{array}{l}\text { Characteristic } \\
\text { nature of } \\
\text { vaccination }\end{array}$ & Producers & Clinical phases & $\begin{array}{l}\text { Vaccine utility } \\
\text { for other viruses }\end{array}$ & Ref. \\
\hline $49 \mathrm{VVnr}$ & $\begin{array}{l}\text { Viral vector (non- } \\
\text { replicating) }\end{array}$ & $\begin{array}{l}\text { COH04S1 (MVA- } \\
\text { SARS-2-S) }\end{array}$ & $\begin{array}{l}\text { Vaccine holds the } \\
\text { SARS-CoV-2 spike } \\
\text { and nucleocapsid } \\
\text { proteins inserted } \\
\text { into the MVA } \\
\text { platform that can } \\
\text { replicate DNA within } \\
\text { cells. Thus it } \\
\text { generates novel CoV } \\
\text { protein expression to } \\
\text { trigger host } \\
\text { immunity against } \\
\text { the virus }\end{array}$ & $\begin{array}{l}\text { City of Hope National } \\
\text { Medical Center }\end{array}$ & Phase 1 NCT04639466 & $\begin{array}{l}\text { Vaccine in } \\
\text { development }\end{array}$ & 148 \\
\hline $50 \mathrm{VVr}$ & $\begin{array}{l}\text { Viral vector } \\
\text { (replicating) }\end{array}$ & $\begin{array}{l}\text { rVSV-SARS-CoV- } \\
\text { 2-S vaccine }\end{array}$ & $\begin{array}{l}\text { rVSV- } \Delta \mathrm{G} \text {-spike } \\
\text { stimulated a safe, } \\
\text { efficient and } \\
\text { adequate } \\
\text { neutralizing } \\
\text { antibody. } \\
\text { Vaccination leads to } \\
\text { lower morbidity, } \\
\text { protects lungs, and } \\
\text { provides fast viral } \\
\text { clearance }\end{array}$ & IIBR, Israel & Phase $1 / 2$ NCT04608305 & $\begin{array}{l}\text { Vaccine in } \\
\text { development }\end{array}$ & 149 \\
\hline $\begin{array}{c}51 \mathrm{VVr}+ \\
\text { APC }\end{array}$ & $\begin{array}{l}\text { Viral vector } \\
\text { (replicating) }+ \\
\text { APC }\end{array}$ & $\begin{array}{l}\text { Dendritic cell } \\
\text { vaccine AV- } \\
\text { COVID-19: } \\
\text { contains } \\
\text { autologous } \\
\text { dendritic cells } \\
\text { load with } \\
\text { antigens from } \\
\text { SARS-CoV-2, } \\
\text { with/without } \\
\text { GM-CSF }\end{array}$ & $\begin{array}{l}\text { Produced from } \\
\text { isolated peripheral } \\
\text { blood monocytes } \\
\text { from patients. } \\
\text { Monocytes are then } \\
\text { distinguished into } \\
\text { dendritic cells with } \\
\text { GM-CSF and IL=4 }\end{array}$ & $\begin{array}{l}\text { Aivita Biomedical, } \\
\text { Inc. }\end{array}$ & $\begin{array}{l}\text { Phase 1/2 NCT04690387 } \\
\text { NCT04386252 }\end{array}$ & $\begin{array}{l}\text { Vaccine in } \\
\text { development }\end{array}$ & 150 \\
\hline
\end{tabular}


Table 4 (Contd.)

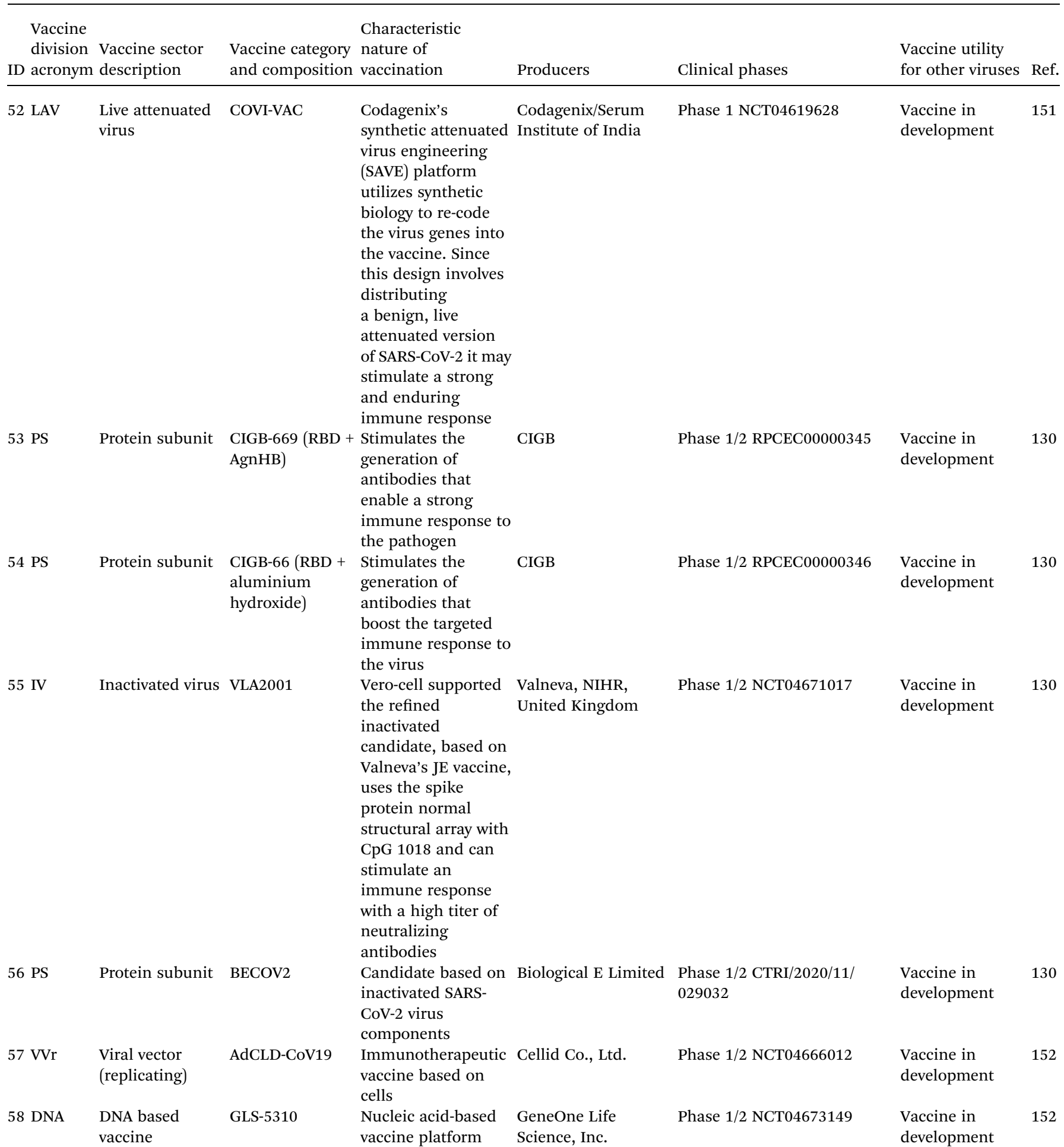


Table 4 (Contd.)

\begin{tabular}{|c|c|c|c|c|c|c|c|}
\hline $\begin{array}{r}\text { Vaccine } \\
\text { division } \\
\text { ID acronym }\end{array}$ & $\begin{array}{l}\text { Vaccine sector } \\
\text { description }\end{array}$ & $\begin{array}{l}\text { Vaccine category } \\
\text { and composition }\end{array}$ & $\begin{array}{l}\text { Characteristic } \\
\text { nature of } \\
\text { vaccination }\end{array}$ & Producers & Clinical phases & $\begin{array}{l}\text { Vaccine utility } \\
\text { for other viruses }\end{array}$ & Ref. \\
\hline 60 PS & Protein subunit & $\begin{array}{l}\text { Recombinant } \\
\text { protein vaccine } \\
\text { S-268019 (based } \\
\text { on Baculovirus } \\
\text { expression vector } \\
\text { system) }\end{array}$ & $\begin{array}{l}\text { Vaccine is based on } \\
\text { recombinant protein } \\
\text { units together with } \\
\text { GSK; development of } \\
\text { mRNA vaccine by } \\
\text { Sanofi, in } \\
\text { collaboration with } \\
\text { Translate Bio. } \\
\text { Preclinical data } \\
\text { revealed that the two } \\
\text { immunizations of } \\
\text { the mRNA based } \\
\text { vaccine stimulated } \\
\text { high neutralizing } \\
\text { antibody levels equal } \\
\text { to those produced in } \\
\text { infected humans }\end{array}$ & Shionogi & Phase $1 / 2$ jRCT2051200092 & $\begin{array}{l}\text { Vaccine in } \\
\text { development }\end{array}$ & 130 \\
\hline
\end{tabular}

${ }^{a}$ Globally, vaccine producers have the ability to achieve rapid development of highly efficient, safe - minimum toxicity - vaccines.

In order to determine the similarities and differences between previously available vaccines and COVID-19 vaccines, the Bacillus Calmette-Guérin (BCG) vaccine against tuberculosis is provided as one more example; it confers a wide range of immunity against other infections, and it also may minimize the intensity of COVID-19. Moreover one epidemiological analyses provided universal connections between the vaccinations of BCG and COVID-19 mortality: the suggestion of BCG vaccination results on COVID-19 fatality are dominated by socio-economical and demographical variations between countries. In the wake of reducing the manifold distracting factors, many substantial connections between the BCG vaccination and decreased COVID-19 fatalities were perceived. Obviously this investigation emphasizes the necessity for an intrinsic mechanism of studies supporting BCG vaccination effects on COVID-19, and also for clinical evaluation to control the COVID-19 pandemic. ${ }^{99 b}$

COVID-19 is a serious respiratory related disease, so the scientific and medicinal community are working hard across the globe to develop a vaccine. Presently, around sixty vaccine candidates are on trial in many countries. Now, nearing twenty candidate vaccines are in phase 3 clinical trials. Gratifyingly, seven vaccines have been approved in many countries.

\section{Conclusions}

Globally, as of January 2021, there have been around 88 million COVID-19 cases, including nearly 1.9 million fatalities, WHO have registered (see WHO Covid-19 case report). ${ }^{99 d}$ These numbers are expected to increase further, so there is an 
emergency requirement to produce vaccines to protect people. Several candidates vaccines are being developed which are in preclinical and clinical trials. The mechanism of action of these candidates varies significantly, as better knowledge becomes available $^{\mathbf{1 5 4 a}}$ about this virus, researchers can adapt their design so if one candidate shows low efficacy, another one may be more active.

Similarly, different demographics may necessitate the need for designing vaccines with different mechanisms of action. The time required for the various stages of clinical trials needs to be shortened (without compromising on the ethics and safety) to achieve the desired goal in a short period of time. ${ }^{154 b}$ Finally, manufacturing such large quantities of the vaccine or vaccines, quickly (without compromising on the quality, purity and efficacy) and distributing them to all parts of the world is another problem which the present planners have not faced before. This requires sufficient manufacturing capacity, availability of raw materials, logistics and several other factors. Also, as all resources are diverted towards SARS-CoV-2, epidemiologists and public health organizations should not lose track of their fight against other viruses. ${ }^{155}$

The current assemblage of vaccine developers ${ }^{156 a}$ may reward researchers with increased capability, as numerous basic, transformational and preclinical statistical data have become available during coronavirus exploration. These factors combine together as a substantial promising source for rapid vaccine development. ${ }^{156 b}$

Since, December 2020, some new vaccines have emerged and also have been approved by certain national regulatory authorities for use against COVID-19. Amongst these, as per the universal expectations of the WHO EUL/PQ assessment, the Pfizer vaccine and some other candidates have been approved. More studies on vaccine aspirant efficacy and safety results, ${ }^{157}$ including on the Moderna and AstraZeneca vaccine, therein have been widely reported, and AstraZeneca have published their results in well reputed journals. Thus we are eagerly expecting more potential COVID-19 vaccine candidates will be offered to governing authorities for approval in the coming years. Gratifyingly, the growth of many efficient COVID-19 vaccine aspirants under clinical trials is fascinating. When the vaccine candidates are proven to be benign and efficient, they need to be acknowledged by the governing authorities, produced to the necessary standard, and distributed. WHO is collaborating all over the world to assist with the roles in this process, which includes facilitating reasonable access to safe and effective COVID-19 vaccines for everyone.

\section{Author contributions}

KD and SA equally contributed to the collection of data and developed the entire manuscript. MD corrected the manuscript. SG and ST assisted in drafting.

\section{Conflicts of interest}

We have no conflicts of interest.

\section{Acknowledgements}

KD thanks the Science and Engineering Research Board (SERB), New Delhi, India for the National Post-Doctoral Fellow (NPDF) [Project No. PDF/2017/001743].

\section{References}

1 J. M. Ryan, R. L. Jonathan and V. Olivia, Chem. Rev., 2020, 120, 3210-3229.

2 Y. Tingting, Z. Zifu, G.-S. Adolfo, S. Michael and G. D. G. Bruno, Angew. Chem., Int. Ed., 2020, 59, 1888518897.

3 B. Greenwood, Philos. Trans. R. Soc., B, 2014, 369, 20130433.

4 K. A. Smith, Front. Immunol., 2011, 2, 1-6.

5 A. S. Clem, J. Global Infect. Dis., 2011, 3, 73-78.

6 L. B. Nicholson, Essays Biochem., 2016, 60, 275-301.

7 J. Lu, G. Lu, S. Tan, J. Xia, H. Xiong, X. Yu, Q. Qi, X. Yu, L. Li, H. Yu, N. Xia, T. Zhang, Y. Xu and J. Lin, Cell Res., 2020, 30, 936-939.

8 B. E. Eldred, A. J. Dean, T. M. McGuire and A. L Nash, Med. J. Aust., 2006, 184, 170-175.

9 (a) W. Shang, Y. Yang, Y. Rao and X. Rao, npj Vaccines, 2020, 5, 18; (b) C. Edwards, West. J. Med., 2001, 174, 197-198; (c) K. Chumakov, E. Ehrenfeld, E. Wimmer and V. I. Agol, Nat. Rev. Microbiol., 2007, 5, 952-958; (d) H. Wang, Y. Zhang, B. Huang, W. Deng, Y. Quan, W. Wang, W. Xu, Y. Zhao, N. Li, J. Zhang, H. Liang, L. Bao, Y. Xu, L. Ding, W. Zhou, H. Gao, J. Liu, P. Niu, L. Zhao, W. Zhen, H. Fu, S. Yu, Z. Zhang, G. Xu, C. Li, Z. Lou, M. Xu, C. Qin, G. Wu, G. F. Gao, W. Tan and X. Yang, Cell, 2020, 82, 713-721; (e) N. Chauhan, S. Soni, A. Gupta, M. Aslam and U. Jain, J. Med. Virol., 2021, 93, 1967-1982; $(f)$ N. Lurie, M. Saville, R. Hatchett and J. Halton, N. Engl. J. Med., 2020, 382, 1969-1973.

10 C. Zhang, G. Maruggi, H. Shan and J. Li, Front. Immunol., 2019, 10, 594-606.

11 B. Pulendran and R. Ahmed, Nat. Immunol., 2011, 12, 509517.

12 V. Vetter, G. Denizer, L. R. Friedland, J. Krishnan and M. Shapiro, Ann. Med., 2018, 50, 110-120.

13 A. H. Ellebedy and R. Ahmed, The Vaccine Book, 2nd edn, 2016, pp. 283-310. DOI: 10.1016/B978-0-12-8021743.00015-1.

14 E. De Clercq and G. Li, Clin. Microbiol. Rev., 2016, 29, 695747.

15 K. Bharati and S. Vrati, Proc. Natl. Acad. Sci., India, Sect. B, 2012, 82, 181-198.

16 (a) https://clinicaltrials.gov; (b) https://www.drugbank.ca; (c) D. E. Speiser and M. F. Bachmann, Vaccines, 2020, 8, 404; (d) S. Tavakol, M. S. Alavijeh and A. M. Seifalian, Curr. Pharm. Des., 2021, 27, 1553-1563; (e) S. P. Kaur and V. Gupta, Virus Res., 2020, 288, 198114.

17 J. P. Fox, Rev. Infect. Dis., 1984, 6, S352-S355.

18 M. P. Kostinov, A. P. Cherdantsev, A. I. Kuselman, N. K. Akhmatova, A. M. Kostinova, E. Viktorovna, 
D. E. Olegonva and A. M. Kostinov, Hum. Vaccines Immunother., 2018, 14, 2971.

19 ClinicalTrials.govIdentifier: NCT03131765, April 27, 2017.

20 (a) J. S. Tregoning, R. F. Russell and E. Kinnear, Hum. Vaccines Immunother., 2018, 14, 550-564; (b) https:// www.prnewswire.com/news-releases/adimmunesquadrivalent-flu-vaccine-approved-by-tfda-300455062.html.

21 Quadrivalent-inactivated-influenza-vaccine-adimmune-

corporation, Reactions Weekly, 2021, 1837, 611.

22 (a) ClinicalTrials.gov Identifier: NCT03120364, April 19, 2017; (b) S. J. Lee, H. J. Park, H. L. Ko, J. E. Lee, H. J. Lee, H. Kim and J. H. Nam, Immun., Inflammation Dis., 2020, 8, 216-227.

23 J. J. Y. Sung and H. L. Yuen, Curr. Opin. Mol. Ther., 2006, 8, 150-155.

24 ClinicalTrials.govIdentifier: NCT00920218 December 12, 2017.

25 K. Mahmood, S. Pelkowski and J. J. Donnelly, Hum. Vaccines Immunother., 2013, 9, 1894-1902.

26 A. K. Mc Elory, R. S. Akondy, C. W. Davis, A. H. Ellebedy, A. K. Mehta, C. S. Kraft, G. M. Lyon, B. S. Ribner, J. Varkey and J. Sidney, Proc. Natl. Acad. Sci. U. S. A., 2015, 112, 4719-4724.

27 (a) www.adisinsight.springer.com; (b) http:// zyduscadila.com/research.

28 (a) www.rxlist.com/flucelvax-drug.html; (b) http:// europa.eu/en/documents/product-information/flucelvaxtetra-epar-product-information_en.pdf.

29 (a) www.medbroadcast.com/drug/getdrug/vaxigrip; http://products.sanofi.com.au/vaccines/ VAXIGRIP_NZ_CMI.pdf.

30 (a) B. Brandenburg, W. K. Klaren, C. Tang, M. V. Bujny, H. J. W. Korse, T. Kwaks, J. J. Otterstrom, J. Juraszek, A. M. Van Oijen and R. Vogels, PLoS One, 2013, 8, 80034; (b) C. Yamazaki, M. Sugiyama, T. Ohta, H. Hemmi, E. Hamada, I. Sasaki, Y. Fukuda, T. Yano, M. Nobuoka, T. Hirashima, A. Iizuka, K. Sato, T. Tanaka, K. Hoshino and T. Kaisho, J. Immunol., 2013, 190, 296-306.

31 H. Juin, H. Lim, J. A. Lee, H. J. Kim, J. W. Kim, J. Y. Hyeon, S. G. Yeo, J. W. Lee, J. S. Yoo, Y. K. Choi and S. W. Lee, PLoS One, 2017, 12, 0178259.

32 http://www.lybrate.com/amp/medicine/cadiflu-s-vaccine.

33 P. T. Boer, J. K. Kelso, N. Halder, T. P. L. Nguyen, J. Modyes, C. Cohen, I. G. Barr, M. J. Postma and G. J. Milne, Vaccine, 2018, 836, 997-1007.

34 Influenza virus RIV4 vaccine (Flublok Quadrivalent): VAERS reports, Reactions Weekly, 2021, 1847, 8.

35 I. V. Dolzhikova, O. V. Zubkova, A. I. Tukhvatulin, A. S. Dzharullaeva, Z. M. Yukhvatulina, D. V. Shcheblyakov, M. M. Shmarov, E. A. Tokarskaya, Y. V. Simakova, D. A. Egorova, D. N. Scherbinin, I. L. Tutykhina, A. A. Lysenko, A. V. Lostranoy, P. G. Gancheva, T. A. Ozharovskaya, B. V. Belugin, L. V. Kolobukhina, V. B. Pantyukhov, S. I. Syromyatnikova, I. V. Shatokhina, T. V. Sizikova, I. G. Rumyantseva, A. F. Andrus, N. V. Boyarskaya, A. N. Voytyuk, V. F. Babira, S. V. Volchikhina,
D. A. Kutaev, A. N. Bel'skih, K. V. Zhdanov, S. M. Zakharenko, S. V. Borisevich, D. Y. Logunov, B. S. Naroditsky and A. L. Gintsburg, Hum. Vaccines Immunother., 2017, 13, 613-620.

36 (a) https:/www.who.int/teams/health/vaccines-quality/ poliomyelitis; (b) A. R. Hinman, J. P. Koplan, W. A. Orenstein, E. W. Brink and B. M. N. Kowane, Am. J. Public Health, 1998, 78, 291-295.

37 N. Bhandari, T. R. Chandola, A. Bavdekar, J. John, K. Antony, S. Taneja, N. Goyal, A. Kawade, G. Kang, S. Singh Rathore, S. Juvekar, J. Muliyil, A. Arya, H. Shaikh, V. Abraham, S. Vrati, M. Proschan, R. Kohberger, G. Thiry, R. G. Harry, B. Greenberg, G. Curlin, K. Mohan, G. V. J. A. Harshavardhan, S. Prasad, T. S. Rao, J. Boslego and M. K. Bhan, Lancet, 2014, 383, 2136-2143.

38 W. S. Choi, J. Y. Noh, J. Y. Song, H. J. Cheong, S. H. Wie, J. S. Lee, J. Lee, S. W. Kim, H. W. Jeong, S. I. Jung, Y. S. Kim, H. J. Woo, K. H. Kim, H. Kim and W. J. Kim, Hum. Vaccines Immunother., 2017, 13, 1653-1660.

39 J. Lee, K. Y. Lee, J. H. Kim, C. S. Kim, B. W. Eun, H. M. Kim, D. H. Kim, Y. J. Hong, Y. Y. Choi, D. S. Jo, S. H. Ma and J. H. Kang, J. Korean Med. Sci., 2018, 26, 100.

40 J. Arroyo, C. Miller, J. Catalan, G. A Myers, M. S. Ratterree, D. W Trent and T. P Monath, J. Virol., 2004, 78, 12497.

41 (a) J. Schon, W. R. M. Gorka, M. Schwemmle, M. Beer and D. Hoffmann, npj Vaccines, 2020, 5, 40; (b) http:// www.who.int/influenza/resources/avin_influenza/en.

42 A. Luxembourg, D. Brown, C. Bouchard, A. R. Giuliano, O. E. Lversen, E. A. Joura, M. E. Penny, J. A. Restrepo, J. Romaguera, R. Maansson, E. Moeller, M. Ritter and J. Chen, Hum. Vaccines Immunother., 2015, 11, 1313-1322.

43 M. Endo, M. Tanishima, K. Lbarai, K. Hayashida, T. Fukuda, T. Tanable, T. Naruse, Y. Kino and K. Ueda, Influenza Other Respir. Viruses, 2020, 14, 551-563.

44 ClinicalTrials.govIdentifier: NCT02977715, September, 23, 2020.

45 L. Turtle and T. Solomon, Nat. Rev. Neurol., 2018, 14, 298313.

46 http://www.who.int/immunizati_standards/ vaccine_quality/ fluzone_sanofi_pasteur_product_insert.pdf.

47 (a) http://www.fda.gov/media/115785/download; (b) http:// www.immunizationinfo.com/flulaval-vaccine/amp.

48 Y. Y. Syed, Paediatr. Drugs, 2019, 21, 501.

49 ClinicalsTrials.govIdentifier: NCT02148211, May 28, 2014. 50 (a) J. Arroyo, C. Miller, J. Catalan, G. A Myers, M. S Ratterree, D. W. Trent and T. P. Monath, J. Virol., 2004, 78, 1249712507; (b) M. G. Moloney, A. P. Goncalvez, J. Catalan, V. Lecouturier, Y. G. Chambaz, F. Diaz, F. M. Arocho, R. C. Gomila, M. C. Bernard, R. Oomen, S. Delagrave, N. Burdin, H. Kleanthous, N. Jackson, J. Heinrichs and K. V. Pugachev, Sci. Rep., 2018, 8, 13206.

51 G. M. Keating, G. L Plosker and K. A. L. Williamson, Biodrugs, 2012, 26, 425-430.

52 (a) J. H. C. M. Kreijtz, R. A. M. Fouchier and G. F. Rimmelzwaan, Virus Res., 2011, 162, 19-30; (b) 
S. S. Wong and R. J. Webby, Clin. Microbiol. Rev., 2013, 26, 476-492.

$53 \mathrm{X} . \mathrm{Wu}, \mathrm{P}$. Chen, H. Lin, X. Hao and Z. Liang, Hum. Vaccines Immunother., 2016, 12, 2603-2610.

54 B. M. Laksono, R. D. Vries, R. J. Verburgh, E. G. Visser, A. deong, P. L. A. Fraaij, W. L. M. Ruijs, D. F. Nieuwenhuijse, H. J. Ham, M. P. G. Koopmans, M. C. van Zelm, A. D. M. E. Osterhaus and R. L. de Swart, Nat. Commun., 2018, 9, 4944.

55 N. R. Hegde, D. Kumar, P. P. Rao, P. K. Kumari, Y. Kaushik, R. Ravikrishnan, S. D. Prasad and K. M. Ella, Vaccine, 2014, 32, 3636.

56 A. Choudhry, S. Singh, S. Khare, A. Rai, D. S. Rawat, R. K. Aggarwal and L. S. Chauhan, Indian J. Med. Res., 2012, 135, 534-537.

57 Y. N. Lamb, Drugs, 2019, 79, 1337-1348.

58 C. M. Trombetta, E. Gianchecchi and E. Montomoli, Hum. Vaccines Immunother., 2018, 14, 657-670.

59 K. J. Kallen, R. Heidenreich, M. Schnee, B. Petsch, T. Schlake, A. P. Baumh, B. Scheel, S. D. Koch and M. F. Mleczek, Hum. Vaccines Immunother., 2013, 9, 22632276.

60 J. S. Tregoning, R. F. Russell and E. Kinnear, Hum. Vaccines Immunother., 2018, 14, 550-564.

61 N. Chotirosniramit, P. Sugandhavesa, L. Aurpibul, S. Thetket, N. Kosashunhanan, T. Supindham, P. Wongkulab, Q. Kaewpoowat, K. Chaiklang, O. Kaewthip, P. Sroysuwan, A. Wongthanee, H. Lerdsamran, P. Puthavathana and K. Suparatpinyo, Hum. Vaccines Immunother., 2012, 8, 1854-1859.

62 H. Reynales, P. Astudillo, S. de Vallière, C. Hatz, P. Schlagenhauf, B. Rath, P. Velentgas, A. Fariña, V. Sales Carmona and N. Groth, Vaccine, 2012, 30, 6436-6443.

63 P. Hallberg, H. Smedje, N. Eriksson, H. Kohnke, M. Daniilidou, I. Öhman, Q. Y. Yue, M. Cavalli, C. Wadelius, P. K. E. Magnusson, A. M. Landtblom and M. Wadelius, EBioMedicine, 2019, 40, 595-604.

64 N. A. T. van der Maas, S. Godefrooij, P. E. Vermeer-de Bondt, H. E. de Melker and J. Kemmeren, Hum. Vaccines Immunother., 2016, 12, 1027-1032.

65 V. Talayev, I. Zaichenko, M. Svetlova, A. Matveichev, O. Babaykina, E. Voronina and A. Mironov, Vaccine, 2020, 38, 6645-6655.

66 (a) https://www.sciencedirect.com/topics/medicine-anddentistry/hong-kong-influenza; (b) W.-S. Ryu, Molecular Virology of Human Pathogenic Viruses, 2017.

67 J. M. Vernon and T. Nolan, Expert Rev. Vaccines, 2011, 10, 35-43.

68 N. J. Carter and G. L. Plosker, BioDrugs, 2008, 22, 279-292.

69 I. Manini, A. Domnich, D. Amicizia, S. Rossi, T. Pozzi, R. Gasparini, D. Panatto and E. Montomoli, Expert Rev. Vaccines, 2015, 14, 789-804.

70 A. Nalca and E. E. Zumbrun, Drug Des., Dev. Ther., 2010, 4, 71-79.

71 (a) https://www.immunizationinfo.com/afluria-vaccine; $(b)$ V. A. Statler, F. R. Albano, J. Airey, D. C. Sawlwin,
A. Graves, J. V. Matassa, E. H. J. Edelman and G. S. Marshall, Vaccine, 2019, 37, 343-351.

72 C. A. Robertson, C. A. D. Granados, M. D. Decker, A. Chit, M. Mercer and D. P. Greenberg, Expert Rev. Vaccines, 2016, 15, 1495-1505.

73 (a) https:/www.ema.europa.eu/en/documents/productinformation/covid-19-vaccine moderna-epar-productinformation_en.pdf; (b) N. Pardi, M. J. Hogan, F. W. Porter and D. Weissman, Nat. Rev. Drug Discovery, 2018, 17, 261.

74 I. Manini, A. Domnich, D. Amicizia, S. Rossi, T. Pozzi, R. Gasparini, D. Panatto and E. Montomoli, Expert Rev. Vaccines, 2015, 14, 789-804.

75 G. Pauli, T. H. Larsen, S. Rak, F. Horak, E. Pastorello, R. Valenta, A. Purohit, M. Arvidsson, A. Kavina, J. W. Schroeder, N. Mothes, S. Spitzauer, A. Montagut, S. Galvain, M. Melac, C. André, L. K. Poulsen and H. J. Malling, J. Allergy Clin. Immunol., 2008, 122, 951-960.

76 M. Margarita, G. Lorenzo and M. J. Fenton, Chest, 2013, 143, 502-510.

77 D. T. O. Hagan, L. R. Friedland, E. Hanon and A. M. Didierlaurent, Curr. Opin. Immunol., 2017, 47, 93-102. 78 J. P. Mc Gettigan, Expert Rev. Vaccines, 2010, 9, 1177-1186. 79 M. Sanford and G. M. Keating, Drugs Aging, 2010, 27, 159176.

80 G. M. Keating, BioDrugs, 2016, 30, 243-254.

81 D. M. H. Leslie and R. De Mars, Gynecol. Oncol., 2017, 146, 196-204.

82 J. M. Hyser and M. K. Estes, Curr. Opin. Gastroenterol., 2009, 25, 36-43.

83 G. L. Roels, Med. Microbiol. Immunol., 2015, 204, 69-78.

84 Y. L. Zhao, Y. G. Chen, J. Li, G. X. Han, C. Tian, J. L. Liang, Z. G. Wang, Y. G. Zhu, Z. N. Tian, H. Y. Zhang, Z. J. Wan, Z. L. Liang, S. L. Bi, Z. L. X. Bing and X. Z. Zhi, Zhonghua Liuxingbingxue Zazhi, 2004, 25, 470-473.

85 I. A. de Bruijn, J. Nauta, L. Gerez and A. M. Palache, Vaccine, 2006, 24, 6629-6631.

86 S. S. Wong and R. J. Webby, Clin. Microbiol. Rev., 2013, 26, 476-492.

87 B. Jarvis and D. P. Figgitt, Drugs, 2003, 63, 214-215.

88 F. Wu, S. Zhao, B. Yu, Y.-M. Chen, W. Wang, Z.-G. Song, Y. Hu, Z.-W. Tao, J.-H. Tian, Y.-Y. Pei, M.-L. Yuan, Y.-L. Zhang, F.-H. Dai, Y. Liu, Q.-M. Wang, J.-J. Zheng, L. Xu, E. C. Holmes and Y.-Z. Zhang, Nature, 2020, 579, 265-269.

89 (a) H. Wang, X. Li, T. Li, S. Zhang, L. Wang, X. Wu and J. Liu, Eur. J. Clin. Microbiol. Infect. Dis., 2020, 39, 1629-1635; (b) N. Wang, J. Shang, S. Jiang and L. Du, Front. Microbiol., 2020, 11, 298; (c) Y. D. Li, W. Y. Chi, J. H. Su, L. Ferrall, C. F. Hung and T. C. Wu, J. Biomed. Sci., 2020, 27, 104.

90 P. Zhou, X.-L. Yang, X.-G. Wang, B. Hu, L. Zhang, W. Zhang, H.-R. Si, Y. Zhu, B. Li, C.-L. Huang, H.-D. Chen, J. Chen, Y. Luo, H. Guo, R.-D. Jiang, M.-Q. Liu, Y. Chen, X.-R. Shen, X. Wang, X.-S. Zheng, K. Zhao, Q.-J. Chen, F. Deng, L-L Liu, B. Yan, F.-X. Zhan, Y.-Y. Wang, G.-F. Xiao and Z.-L. Shi, Nature, 2020, 579, 270-273. 
91 (a) L. Vijgen, E. Keyaerts, E. Moës, I. Thoelen, E. Wollants, P. Lemey, A.-M. Vandamme and M. V. Ranset, J. Virol., 2005, 79, 1595-1604; (b) J. Sultana, S. Crisafulli, F. Gabbay, E. Lynn, S. Shakir and G. Trifirò, Front. Pharmacol., 2020, 11, 588654; (c) S. Dotolo, A. Marabotti, A. Facchiano and R. Tagliaferri, Brief. Bioinform., 2020; (d) Y. Zhou, F. Wang, J. Tang, R. Nussinov and F. Cheng, Lancet Glob. Health, 2020, 2, e667-e676.

92 (a) L. Cynthia, Q. Zhou, Y. Li, V. L. V. Garner, S. P. Watkins, L. J. Carter, J. Smoot, A. C. Gregg, A. D. Daniels, S. Jervey and D. Albaiu, ACS Cent. Sci., 2020, 6, 315-331; (b) D. Calina, C. Sarkar, A. L. Arsene, B. Salehi, A. Docea, M. Mondal, M. T. Islam, A. Zaliand and J. S. Rad, Immunol. Res., 2020, 68, 315-324; (c) Y. Dong, T. Dai, Y. Wei, L. Zhang, M. Zheng and F. Zhou, Signal Transduction Targeted Ther., 2020, 5, 237; (d) G. N. A. Rego, M. P. Nucci, A. H. Alves, F. A. Oliveira, L. C. Marti, L. P. Nucci, J. B. Mamani and L. F. Gamarra, Vaccines, 2020, 8, 474; (e) D. D. Li and Q. H. Li, Mil. Med. Res., 2021, 8, 1-15.

93 H. Li, Y. Zhou, M. Zhang, H. Wang, Q. Zhao and J. Liu, Antimicrob. Agents Chemother., 2020, 64, e00483.

94 (a) R.-G. Marjorie, Curr Opin Biotechnol., 2007, 18, 546-556; (b) G. N. A. Rego, M. P. Nucci, A. H. Alves, F. A. Oliveira, L. C. Marti, L. P. Nucci, J. B. Mamani and L. F. Gamarra, Vaccines, 2020, 8, 474.

95 W. H. Chen, U. Strych, P. J. Hotez and M. E. Bottazzi, Curr. Trop. Med. Rep., 2020, 7, 61-64.

96 W. Ning, S. Jian, J. Shibo and D. Lanying, Front. Microbiol., 2020, 11, 298.

97 R. António, C. M. M. Maria, R. C. Leda, J. T. C. Manuel and M. A. Paula, Expert Rev. Vaccines, 2010, 9, 1149-1176.

98 L. Jie, U. Laura, S. Erica, R. T. Deborah and V. Raphael, Viral Immunol., 2013, 126-132.

99 (a) https://www.who.int/publications/m/item/draftlandscape-of-covid-19-candidate-vaccines;

L. E. Escobara, A. M. Cruz and C. B. Mury, Proc Natl. Acad. Sci., 2020, 117, 27741-27742; (c) https:// www.clinicaltrials.gov; (d) https://covid19.who.int/.

100 (a) S. Geoghegan, K. P. O'Callaghan and P. A. Offit, Front. Microbiol., 2020, 11, 372; (b) T. H. T. Quach, N. A. Mallis and J. F. Cordero, Matern. Child Health J., 2020, 24, 229240; (c) L. K. Boerner, ACS Cent. Sci., 2020, 6, 89-92; (d) M. Famulare, C. Selinger, K. A. McCarthy, P. A. Eckhoff and G. C. Couture, PLoS Biol., 2018, 16, e2002468; (e) D. A. Geier, J. K. Kern and M. R. Geier, BMC Pediatr., 2019, 19, 325.

101 R. Palacios, E. G. Patiño, R. de Oliveira Piorelli, M. Tilli Reis Pessoa Conde, A. Paula Batista, G. Zeng, Q. Xin, E. G. Kallas, J. Flores, C. F. Ockenhouse and C. Gast, Trials, 2020, 21, 853.

102 S. Xia, K. Duan, Y. Zhang, D. Zhao, H. Zhang, Z. Xie, X. Li, C. Peng, Y. Zhang, W. Zhang, Y. Yang, W. Chen, X. Gao, W. You, X. Wang, Z. Wang, Z. Shi, Y. Wang, X. Yang, L. Zhang, L. Huang, Q. Wang, J. Lu, Y. Yang, J. Guo, W. Zhou, X. Wan, C. Wu, W. Wang, S. Huang, J. Du, Z. Meng, A. Pan, Z. Yuan, S. Shen, W. Guo and X. Yang, JAMA, J. Am. Med. Assoc., 2020, 324, 951-960.
103 M. Oysey, S. A. C. Clemens, S. A. Madhi, et al., Lancet, 2021, 397, 99-111.

104 S. Ahamad, S. Branch, S. Harrelson, M. K. Hussain, M. Saquib and S. Khan, Eur. J. Med. Chem., 2021, 209, 112862.

105 D. Y. Logunov, I. V. Dolzhikova, O. V. Zubkova, A. I. Tukhvatulin, D. V. Shcheblyakov, A. S. Dzharullaeva, D. M. Grousova, A. S. Erokhova, A. V. Kovyrshina, A. G. Botikov, F. M. Izhaeva, O. Popova, T. A. Ozharovskaya, I. B. Esmagambetov, I. A. Favorskaya, D. I. Zrelkin, D. V. Voronina, D. N. Shcherbinin, A. S. Semikhin, Y. V. Simakova, E. A. Tokarskaya, N. L. Lubenets, D. A. Egorova, M. M. Shmarov, N. A. Nikitenko, L. F. Morozova, E. A. Smolyarchuk, E. V. Kryukov, V. F. Babira, S. V. Borisevich, B. S. Naroditsky and A. L. Gintsburg, Lancet, 2020, 396, 887. 106 J. Sadoff, M. Le Gars, G. Shukarev, D. Heerwegh, C. Truyers, A. M. de Groot, J. Stoop, S. Tete, W. Van Damme, I. LerouxRoels, P.-J. Berghmans, M. Kimmel, P. Van Damme, J. de Hoon, W. Smith, K. E. Stephenson, S. C. De Rosa, K. W. Cohen, M. J. McElrath, E. Cormier, G. Scheper, D. H. Barouch, J. Hendriks, F. Struyf, M. Douoguih, J. Van Hoof and H. Schuitemaker, N. Engl. J. Med., 2021, 384, 1824-1835.

107 E. Tumban, Viruses, 2021, 13, 54.

108 L. R. Baden, H. M. El Sahly, B. Essink, K. Kotloff, S. Frey, R. Novak, D. Diemert, S. A. Spector, N. Rouphael, C. B. Creech, J. McGettigan, S. Khetan, N. Segall, J. Solis, A. Brosz, C. Fierro, H. Schwartz, K. Neuzil, L. Corey, P. Gilbert, H. Janes, D. Follmann, M. Marovich, J. Mascola, L. Polakowski, J. Ledgerwood, B. S. Graham, H. Bennett, R. Pajon, C. Knightly, B. Leav, W. Deng, H. Zhou, S. Han, M. Ivarsson, J. Miller and T. Zaks, N. Engl. J. Med., 2021, 384, 403-416.

109 F. P. Polack, S. J. Thomas, N. Kitchin, J. Absalon, A. Gurtman, S. Lockhart, J. L. Perez, G. P. Marc, E. D. Moreira, C. Zerbini, R. Bailey, K. A. Swanson, S. Roychoudhury, K. Koury, P. Li, W. V. Kalina, D. Cooper, R. W. Frenck, L. L. Hammitt, Ö. Türeci, H. Nell, A. Schaefer, S. Ünal, D. B. Tresnan, S. Mather, P. R. Dormitzer, U. Şahin, K. U. Jansen and W. C. Gruber, N. Engl. J. Med., 2020, 383, 2603-2615.

110 R. Chakraborty and S. Parvez, Biochem. Pharmacol., 2020, 180, 114184.

111 G. A. Poland, I. G. Ovsyannikova and R. B. Kennedy, Lancet, 2020, 396, 1595-1606.

112 T. Li, T. Zhang, Y. Gu, S. Li and N. Xi, Fundam. Res., 2021, 1, 139-150.

113 J. Y. Chung, M. N. Thone and Y. J. Kwon, Adv. Drug Delivery Rev., 2021, 170, 1-25.

114 L. Calzetta, B. L. Ritondo, A. Coppola, M. G. Matera, N. D. Daniele and P. Rogliani, Vaccines, 2021, 9, 341.

115 C. Corti and G. Curigliano, Ann. Oncol., 2021, 32, 569-571. 116 A. K. Yadav, S. Ghosh and A. Kotwal, J. Mar. Med. Soc., 2020, 22, 110.

117 E. U. Haq, J. Yu and J. Guo, Exp. Hematol. Oncol., 2020, 9, 24. 
118 P. Yadav, R. Ella, S. Kumar, D. Patil, S. Mohandas, A. Shete, G. Bhati, G. Sapkal, H. Kaushal, S. Patil, R. Jain, G. R. Deshpande, N. Gupta, K. Agarwal, M. Gokhale, B. Mathapati, S. Metkari, C. Mote, D. D. Patil, B. S. S. Prasad, A. Suryawanshi, M. Kadam, A. Kumar, S. Daigude, S. Gopale, T. Majumdar, D. Mali, P. Sarkale, S. Baradkar, P. Gawande, Y. Joshi, S. Fulari, H. Dighe, S. Sharma, R. Gunjikar, A. Kumar, K. Kalele, V. K. Srinivas, K. Mohan, R. Gangakhedkar, K. Ella, P. Abraham, S. Panda and B. Bhargava, Nat. Commun., 2021, 12, 1386-1394.

119 M. F. Haidere, Z. A. Ratan, S. Nowroz, S. B. Zaman, Y.-J. Jung, H. Hosseinzadeh and J. Y. Cho, Biomol. Ther., 2021, 29, 1.

120 Y.-D. Li, W.-Y. Chi, J.-H. Su, L. Ferrall, C.-F. Hung and T.-C. Wu, J. Biomed. Sci., 2020, 27, 104.

121 C. Chakraborty, A. R. Sharma, M. Bhattacharya, G. Sharma, R. P. Saha and S.-S. Lee, Immune Network, 2021, 21, e5.

122 L. Scarabel, M. Guardascione, M. D. Bo and G. Toffoli, Int. J. Infect. Dis., 2021, 104, 441.

123 R. Simoneaux and S. L. Shafer, ASA Monitor., 2020, 84, 1718.

124 T. M. Karpiński, M. Ożarowski, A. S. Mrozikiewicz, H. Wolski and D. Wlodkowic, Theranostics, 2021, 11, 1690. 125 Q. Huang and J. Yana, Fundam. Res., 2021, 1, 131.

126 S. M. Vrba, N. M. Kirk, M. E. Brisse, Y. Liang and H. Ly, Vaccines, 2020, 8, 680.

127 J. G. Liang, D. Su, T. Z. Song, Y. Zeng, W. Huang, J. Wu, R. Xu, P. Luo, X. Yang, X. Zhang, S. Luo, Y. Liang, X. Li, J. Huang, Q. Wang, X. Huang, Q. Xu, M. Luo, A. Huang, D. Luo, C. Zhao, F. Yang, J. B. Han, Y. T. Zheng and P. Liang, Nat. Commun., 2021, 12, 1346.

128 R. Chakraborty and S. Parvez, Biochem. Pharmacol., 2020, 180, 114184.

129 K. Kucukoglu, N. Faydalı and D. Bul, Med. Chem. Res., 2020, $10,1$.

130 S. Kashte, A. Gulbake, S. F. El-Amin and A. Gupta, Hum. Cell, 2021, 34, 711-733.

131 N. Chauhan, S. Soni, A. Gupta, M. Aslam and U. Jain, J Med Virol, 2021, 93, 1967.

132 L. Scarabel, M. Guardascione, M. D. Bo and G. Toffoli, Int. J. Infect. Dis., 2021, 104, 441.

133 I. Jatoi and J. Fan, Biomater. Transl. Med., 2021, 2, 30.

134 J. S. Tregoning, E. S. Brown, H. M. Cheeseman, K. E. Flight, S. L. Higham, N.-M. Lemm, B. F. Pierce, D. C. Stirling, Z. Wang and K. M. Pollock, Clin. Exp. Immunol., 2020, 202, 162.
135 Z. Strizova, J. Smetanova, J. Bartunkova and T. Milotaa, Int. Arch. Allergy Immunol., 2021, 182, 339.

136 M. Galdiero, M. Galdiero, V. Folliero, C. Zannella, A. De Filippis, A. Mali, L. Rinaldi and G. Franci, Eur. Rev. Med. Pharmacol. Sci., 2021, 25, 2752.

137 S. P. Kaur and V. Gupta, Virus Res., 2020, 288, 198114.

138 B. Stav, B. Tal, P. S. Cederna and R. J. Rohrich, Plast. Reconstr. Surg., 2020, 8, e3206.

139 T. M. Belete, Infect. Drug Resist., 2021, 14, 151.

140 M. P. Lythgoe and P. Middleton, Trends Pharmacol. Sci., 2020, 41, 363.

141 A. Muacevic and J. R. Adler, Cureus, 2020, 12, e8342.

142 J. Pollet, W.-H. Chen and U. Strycha, Adv. Drug Delivery Rev., 2021, 170, 71.

143 M. M. Silveira, G. M. S. G. Moreira and M. Mendonç, Life Sci., 2021, 267, 118919.

144 D. Pushparajah, S. Jimenez, S. Wonga, H. Alattas, N. Nafissi and R. A. Slavcev, Adv. Drug Delivery Rev., 2021, 170, 113.

145 J. Kim, Y. Eygeris, M. Gupta and G. Sahaya, Adv. Drug Delivery Rev., 2021, 170, 83.

146 M. Bhatta, S. Nandi, S. Dutta and M. K. Saha, Hum. Vaccines Immunother., 2021, 1.

147 Y. Li, R. Tenchov, J. Smoot, C. Liu, S. Watkins and Q. Zhou, ACS Cent. Sci., 2021, 7, 512-533.

148 K. Lundstrom, Viruses, 2021, 13, 317.

149 M. E. Dieterle, D. Haslwanter, R. H. Bortz III, A. S. Herbert, K. Chandran and R. K. Jangra, Cell Host Microbe, 2020, 28, 486.

150 M. K. Saadeldin, A. K. Abdel-Aziz and A. Abdellatif, Med. Hypotheses, 2021, 146, 110365.

151 P. McIntyre, Y. J. Joo, C. Chiu, K. Flanagan and K. Macartney, Aust. Prescr., 2021, 44, 19.

152 J.-H. Yoo, J. Korean Med. Sci., 2021, 36, e54.

153 M. Kool, T. Soullie, M. van Nimwegen, M. A. M. Willart, F. Muskens, S. Jung, H. C. Hoogsteden, H. Hammad and B. N. Lambrecht, J. Exp. Med., 2008, 205, 869.

154 (a) M. Peiris and G. M. Leung, Lancet, 2020, 396, 1467-1469; (b) D. B. Fogel, Contemp. Clin. Trials Commun., 2018, 156164.

155 K. Goodarz, A. Mohammad, M. S. Hossein, T. Niloufar, R. Sajjad, I. Neda and S. H. N. Seyed, Arch. Acad. Emerg. Med., 2020, 8, e41.

156 (a) A. Awadasseid, Y. Wu, Y. Tanaka and W. Zhang, Int. J. Biol. Sci., 2021, 17, 8-19; (b) L. Dai and G. F. Gao, Nat. Rev. Immunol., 2021, 21, 73-82, DOI: 10.1038/s41577-02000480-0.

157 M. C. Castells and E. J. Phillips, N. Engl. J. Med., 2021, 384, 643-649. 